ARCHIVO ESPAÑOL DE ARTE, LXXIX, 315

JULIO-SEPTIEMBRE, pp. 279-298, 2006

ISSN: 0004-0428

\title{
LA FORTUNA DEL CICLO DE 'DANIEL EN \\ EL FOSO DE LOS LEONES' EN LOS PROGRAMAS ESCULTÓRICOS ROMÁNICOS DE GALICIA
}

\author{
POR \\ TERESA C. MOURE PENA \\ Universidad de Santiago de Compostela
}

\begin{abstract}
El objetivo de este artículo se centra en el estudio del ciclo iconográfico de Daniel en el foso de los leones en los programas figurativos del románico gallego. El análisis de las representaciones nos permitirá proponer una serie de teorías sobre la conexión entre figuración y el contexto en el que se dispone y, especialmente el valor y significado que el tema adquiere en el ámbito monástico.

Palabras clave: Daniel; románico; Galicia.
\end{abstract}

This study is focused on the iconographic cycle of Daniel in the Lions Den within the sculptural programs of the Galician Romanesque. Analysis of the representations allows for the proposal of a series of theories concerning the connection between figuration and context, and particularly the value and signification acquired by the theme in the monastic milieu.

Key words: Daniel; Romanesque; Galicia.

Sin duda alguna, el episodio de Daniel en el foso de los leones es uno de los representados con mayor frecuencia en el arte occidental tanto en época paleocristiana como medieval, y muy especialmente en el mundo de la plástica románica. Estamos ante un tema iconográfico que en el caso concreto de la escultura medieval gallega ha sido hasta el momento muy poco estudiado; en el mejor de los casos, aparece referenciado o descrito de manera simplemente anecdótica, sin valorar la razón que motiva su presencia en determinados contextos ${ }^{1}$. Al proceder a su revisión, hemos podido constatar que en los programas figurativos del románico gallego se encuentran lo que

\footnotetext{
${ }^{1}$ Hasta la fecha, el estudio iconográfico del ciclo del Libro de Daniel en el arte medieval gallego se había abordado de manera episódica en los siguientes estudios: Ferrín González, J.R y Carrillo Lista, Ma.P.: "Iconografía del arte medieval en Galicia”, en: Galicia Románica e Gótica. Galicia Terra Única, Xunta de Galicia, 1997, pp. 70-82, esp. pp. 72-73; Idem, "Algunas representaciones de prefiguraciones de Cristo en el arte medieval gallego (ss. XII-XIII)"; en: V Simposium Bíblico Español. La Biblia en el arte y en la Literatura, Vol. II. Arte, 1998, pp. 255-264; Idem, "Escenas eucarísticas en el arte medieval de Galicia" en: V Simposium Bíblico Español. La Biblia en el arte y en la Literatura, Vol. II.
} 
podíamos calificar de "constantes iconográficas"; es decir, el recurso frecuente a esta opción figurativa en determinados contextos arquitectónicos, respondiendo a una clara intencionalidad por parte de los promotores que diseñaron el programa, con objeto de crear un programa específico acorde no sólo con el contexto en el que se va a inscribir sino también de la audiencia a la que va destinado.

En Galicia el tema de Daniel en el foso de los leones adquirirá una extraordinaria popularidad en los ciclos figurativos románicos, muy especialmente en los promovidos por los centros monásticos benedictinos ${ }^{2}$.

Antes de iniciar el estudio sobre la fortuna del ciclo de Daniel en los programas figurativos románicos de Galicia conviene recordar que la iconografía de la condena del profeta se inspira desde sus inicios en dos tradiciones textuales: un primer pasaje en el que se relata cómo el rey Darío, inducido por los sátrapas, condena a Daniel por no haber renunciado a su Dios. El profeta permanecerá en el foso junto a un número indeterminado de leones desde la puesta del sol hasta el alba, siendo auxiliado por Dios, que envía a unos ángeles encargados de salvarlo cerrando la boca de las fieras (Dan. 6, 13-ss). En el segundo pasaje se cuenta cómo Daniel es arrojado al foso de los leones por el pueblo, enfurecido éste después de que aquel hubiera envenenado a su serpiente-ídolo. Según este relato, el profeta permanecerá en el foso durante siete días, y la intervención divina llegará de la mano de Habacuc, llevado por un ángel desde Judea a Babilonia para alimentar a Daniel (Dan 14, 27 y ss) ${ }^{3}$.

Arte, 1998, pp. 241-254; Moure Pena, T.C.: San Salvador de Ferreira de Pantón y San Salvador de Sobrado de Trives. Dos fábricas románicas emparentadas, Tesis de Licenciatura, Universidad de Santiago de Compostela, Facultad de Geografía e Historia, 2002; pp. 134-136; recientemente, Castiñeiras González identificó varias representaciones inspiradas en pasajes del Libro de Daniel en las imágenes que decoran los zócalos del Pórtico de la Gloria de la Catedral compostelana, véase Castiñeiras González, M.A.: "As poéticas das marxes no románico galego: bestiario, fábulas e mundo ó revés", en: Profano y pagano en el arte gallego, Semata, 14, 2003, pp. 293-334.

2 En Galicia existen algunos ejemplos de la antigüedad tardía con iconografía en algún momento identificada como perteneciente al Libro de Daniel, sin poseer, sin embargo, suficientes elementos iconográficos para ser considerados tales, como el fragmento de lauda de estola de Ouvigo (Ourense); Rodríguez Colmenero, A.: "Excavaciones arqueológicas en Ouvigo, Blancos (Orense)", Noticiario Arqueológico Hispánico, 24, 1985, p. 321; Súarez Otero, J.: Lauda de Ouvigo, en: Galicia no Tempo, Santiago de Compostela, 1991, p. 133, nº 37; Idem, Galicia Terra Única. Galicia Castrexa e Romana, Santiago de Compostela, 1997, p. 322.

${ }^{3}$ La explicación para la duplicidad del episodio de la condena se explica porque Dan XIV es un fragmento deuteronónico procedente de relatos apócrifos añadido con posterioridad al Libro de Daniel. En relación con los estudios y publicaciones que abordan la iconografía del Libro de Daniel, contamos con cierto número de títulos: Cabrol, F; Leclerq, H.: Dictionnaire d’Archèologie Chrétienne et de Liturgie, IV/I, París: Libr. Létouzey et Anè, 1920, cols. 221-248; Réau, L.: Iconographie de l’Art Chretien, t. II, París, 1955-1959, 401 y ss; Meinz Mohr, G.: Lexikon der Symbole. Bilder und Zeichen der christichen Kunst, Düsseldorf-Colonia: Eugen Diederichs Verlag, 1971, pp. 133-134; Bocian, M.: Lexikon der Biglischen Personen, Stuttgart: Alfred Knöner Verlag, 1989, pp. 78-83. A esta relación de diccionarios de iconografía viene a sumarse una serie de estudios entre los que podemos citar los siguientes: Le Blant, E.: "Note sur quelques représentations antiques de Daniel dans la foie aux lions", Mémoires de la Société Nationale des Antiquaires de France, V, 1874, pp. 68-78; Weisbach, W.: "Das Daniel-Kapitell im Dom von Chur in der dämoniche Stoffkreis der romanischen Plastik", Phoebus, I, 1946, 3-4, pp. 151-155; Green, R.B.: Daniel in the Lions'Den as an example of Romanesque tipology, Ph. D. diss, University of Chicago, 1948; Cassin, E.: "Daniel dans la fosse aux lions", Revue de 1'Histoire des Religions, CXXXIX, nº 1, 1951, pp. 129-161; Grosset, C.: "L’Origine du théme roman de Daniel", Etudes Mérovingiennes, Actes des journées de Poitiers, 1952, pp. 147-156; Schneider, J.: "Daniel und der Bel zu Babilón", Zeits, f. Schweizer, Archeologie und Kuntgeschichte, Basilea, 1954; Simon, D.: "Daniel and Habakkuk in Aragón", Journal of the British Archaeological Association, XXXVIII, 1075, pp. 50-54; Alexander, S.: Daniel themes in the Irish High Crosses in the Insular Tradition, 1977, pp. 99-114; Salomonson, J.W.: "Voluptatem spectandi non perdat sed mutet: observations sur 1'iconographie du martyre" en Afrique romaine, Ámsterdam, New York; North-Holland Pub. Co., 1979; Mentré, M.: "Iconographie Biblique: le livre de Daniel (Antiquité tardie et Moyen Âge)", en Spania. Estudis d'Antiguitat Tardana oferts en homenatge al profesor Pere de Palol i Salellas, Publicacions de L'Abadia de Montserrat, 1996, pp. 171-176; William, J.: "Daniel in the lions'den: problems in the iconography of a cistercian manuscript", Arte Medievale. Periodico internazionale di critica dellárte medievale, II Serie, anno XIV, nº 1-2, 2000, pp. 49-71, esp. p. 58, fig. 11. Para el 


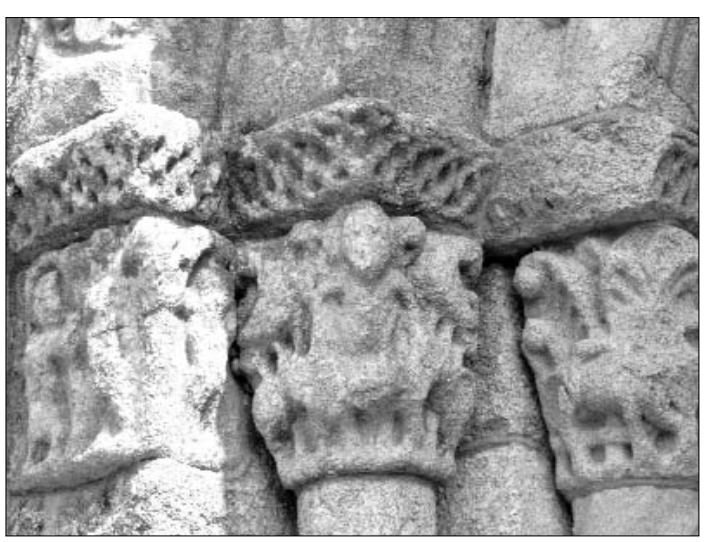

Figura 1. Capiteles de la portada meridional del templo benedictino de San Xulián de Moraime.

La portada meridional del templo benedictino de San Xulián de Moraime-Muxía, A Coruñada buena cuenta de la singular fortuna que el ciclo de Daniel alcanzó en los repertorios de programas monásticos gallegos de la época ${ }^{4}$. En uno de los capiteles del costado izquierdo se representa un personaje, aparentemente desnudo, en una disposición de corte heráldico, de pie y frontal, flanqueado por dos leones en estricta simetría y con las manos situadas sobre sus respectivas cabezas $^{5}$ (fig.1). A primera vista podemos reconocer en esta representación una evocación al episodio de la primera condena de Daniel (Dan 6, 13 y ss). Pero lo realmente excepcional es que el escultor ha elegido este programa monumental para desarrollar un ciclo contrastado de ambos episodios de la damnatio ab bestias, ya que en otro de los capiteles -el situado en el flanco derecho de la portada- se evoca la segunda condena del profeta (Dan 14, 27 y ss): en una de sus caras se figura un ángel junto a otro personaje al que sujeta por los cabellos; éste último ocupa el ángulo del capitel y porta en sus manos un objeto redondo y una especie de bastón. En la cara lateral se dispone el profeta flanqueado por dos leones en el interior de un foso de forma circular. Parece innegable que la escena alude a la intercesión divina a través de la mediación física de Habacuc, transportado por un ángel hasta la fosa (figs.2-3).

Como ya señaló L. Réau en su amplio estudio sobre la iconografía cristiana, no suele ser habitual en los ciclos figurativos occidentales de época medieval la duplicidad y contraposición de las condenas del profeta 6 , si bien se conocen algunos ejemplos en los que se confirma dicha afiliación; así, se puede constatar en la Biblia catalana de San Pere de Rodes, del tercer cuarto del siglo XI -París, BN Ms. Lat. 6, III, f. $65^{\mathrm{V}}, 66^{\mathrm{R}}-$, en donde se habían ensayado experiencias en las que

ámbito peninsular, Moralejo Álvarez, S.: “Aportaciones a la interpretación del programa iconográfico e la Catedral de Jaca", Homenaje a don José María Lacarra de Miguel, vol. I, 1977, pp. 173-198; Idem, "La sculpture romane de la Cathédrale de Jaca. Etat des questions" Les Cahiers de Saint-Michel de Cuxa, no 10, 1979, pp. 94-97; Arbeiter, A.: "Frühe hispanische Darstellungen des Daniel in der Löwengrube", Boreas, 17, 1994, pp. 5-12; Vidal Álvarez, S.: "La iconografía del Libro de Daniel en la escultura hispánica”, Madrider Mitteilungen, 43, 2002, pp. 220-238.

4 Sobre esta portada: Sousa, J.: "La portada meridional de la iglesia de San Julián de Moraime: estudio iconográfico", Brigantium, 4, 1983, pp. 143-155.

5 Ibídem, pp.147-148, fig.7; Yzquierdo Perrín, R.: Galicia Arte. Arte Medieval I, T. X, A Coruña: Ed. Hércules, 1993, pp. 451-456; Ferrín González, J.R; Carrillo Lista, Mª.P.: “Algunas representaciones de prefiguraciones de Cristo en el arte medieval gallego (ss. XII-XIII)"; en: V Simposium Bíblico Español. La Bíblia en el arte y en la Literatura, Vol. II. Arte, pp. 255-264, esp. 260; Ferrín González, J.R.: Arquitectura románica en la "Costa da Morte". De Fisterra a Cabo Vilán, A Coruña: Excma. Diputacción Provincial de A Coruña, 1999, pp. 55-56.

6 Reau, L.: 1955-56, 401. 


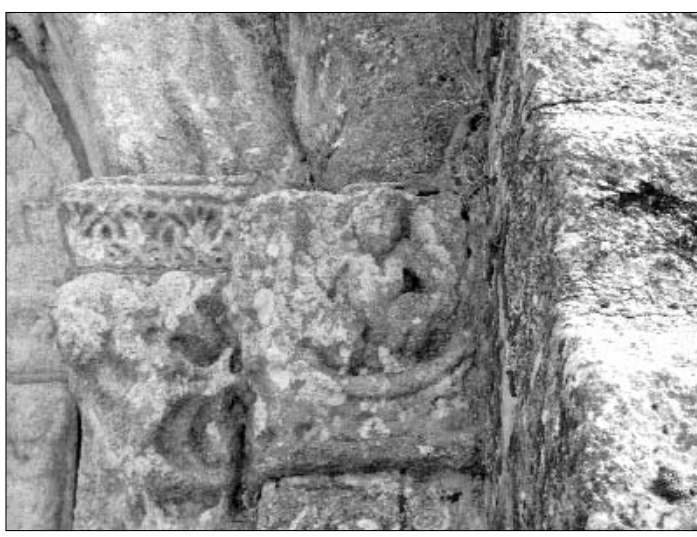

Figura 2. Capiteles de la portada meridional del templo benedictino de San Xulián de Moraime.

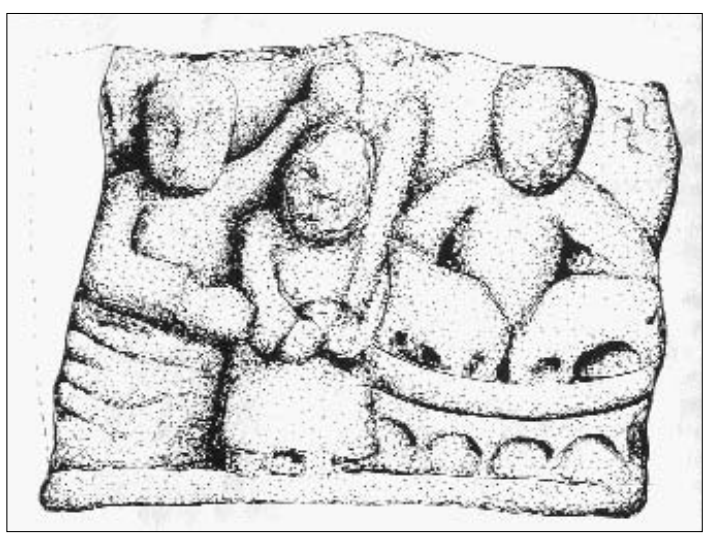

Figura 3. Dibujo de Daniel 14, 27 de San Xulián de Moraime según J. Sousa [J, Sousa.: 1983]

se asociaban figurativamente ambas condenas ${ }^{7}$. Igualmente, en el claustro de Moissac se muestran sendos episodios ilustrando dos capiteles ${ }^{8}$.

La representación de la segunda condena no es excepción en el panorama escultórico románico galaico, como tampoco lo es el contexto en el que aparece, integrado en un programa figurativo de portada ya que, como demostró S. Moralejo en su estudio del programa iconográfico de la portada occidental de la Catedral de Jaca, donde confirma la presencia del tema en uno de sus capiteles ${ }^{9}$, el episodio constituye un "tema de portada" por excelencia, aseverando la identidad que el tema en cuestión adquiere en el contexto monumental de las portadas románicas, como prueba, por ejemplo, la portada principal de la abacial de Santa María de Ripoll -Girona - finales del siglo XII-10, la occidental de San Fedele de Como -Italia- comienzos del siglo XII-, y alguna portada románica francesa de finales del siglo XII como la de Saint Gays de Ydes -Cantal-o la de Beaulieu -Corrèze-11. En el ámbito de la escultura medieval gallega, el episodio aparece representado en una fórmula ya más convencional en uno de los capiteles de la portada occidental del templo de Santiago de A Coruña ${ }^{12}$.

\footnotetext{
${ }^{7}$ Neuss, W.: Die Katalanische Bibelillustration um die Wende des ersten Jarhtausends und die altspanische Buchmalerei, Bonn: Verlag Kurt Schroeder, 1922, Tf. 34, fig. 102; Schunk, H.: "Die Sarkophage von Ecija und Alcaudete", Madrider Mitteilungen, 3, 1962, pp. 119-151, esp. P. 142, fog.6; Cahn, W.: Romanesque Bible Illumination, Ithaca, New York: Cornell University Press, 1982, p. 75, fig. 46; Castiñeiras González, M.A.: 2002, pp. 293-334, esp. P. 295-295, fig.5.

${ }^{8}$ Durliat, M.: La Sculpure Romane de la Route de Saint-Jacques, Mont-de-Marsan: Comité D’Études sur L`Histoire et L'Art de la Gascogne, 1990, pp. 130-131, fig.86.

${ }^{9}$ Moralejo Álvarez, S.: 1977, 173-198, esp. 179-183, figs.1-2. Sobre este capitel véase también: Gómez Moreno, M.: El arte románico español. Esquema de un libro, Madrid, 1934, lám. LXXXI

10 Porter, A.K.: Romanesque Sculpture of the Pilgrimage Roads, Boston, 1923, fig. 578; Melero Moneo, M.: "La propagande politoco-religieuse du programme iconographique de la façade de Sainte-Marie de Ripoll", Cahiers de Civilisation Médiévale, 46, 2003, pp. 135-157, esp. 141-142, fig. 6.

${ }^{11}$ Salvini, R.: Medieval Sculpture, Londres, 1969, fig. 52; Porter, K.A.: 1923, fig. 419, 1222; William, J.: 2000, 4971 , esp. 58, fig. 11 .

12 Castro Fernández, C.: Estudio iconográfico y estilístico de los capiteles de la Catedral de Mondoñedo, Lugo: Servicio de Publicaciones de la Excma. Diputación Provincial de Lugo, 1993, pp. 52-53, figs. 52-54, 57, pp. 114-115, 118; Barral Rivadulla, D.: La Coruña en los siglos XIII al XV. Historia y configuración urbana de una villa de realengo en la Galicia Medieval, Colección Galicia Histórica, A Coruña: Fundación Pedro Barrié de la Maza, 1998, p. 196, lám. XLV.
} 


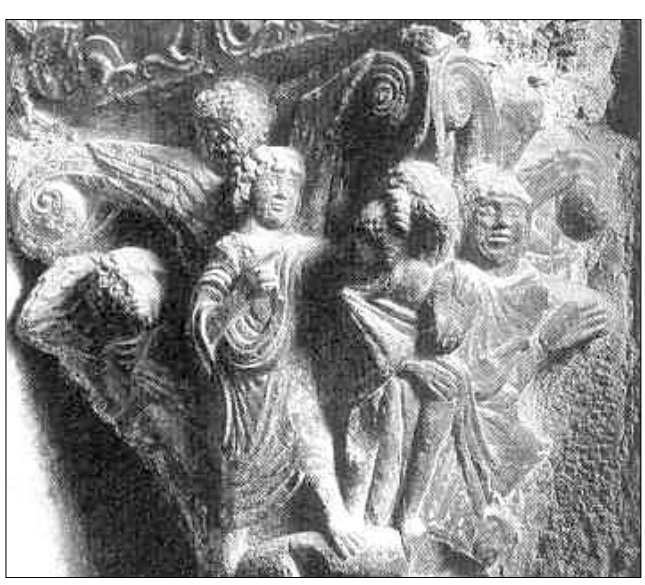

Figura 4. Capitel de la portada occidental de la Catedral de Jaca [Fotografía: Moralejo Álvarez, S.: 1977].

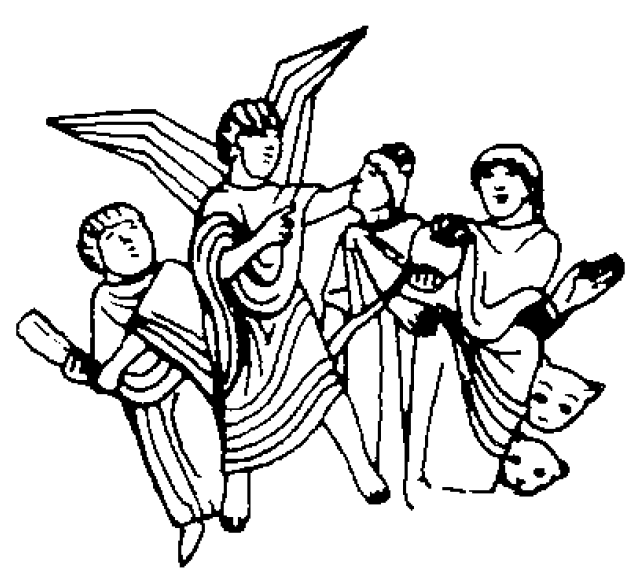

Figura 5. Capitel de la portada occidental de la Catedral de Jaca [Dibujo: Moralejo Álvarez, S.: 1977].

La particular fórmula que se ha dado en Moraime al episodio con el desplazamiento del tema principal -Daniel entre los leones- a uno de los laterales del capitel es análoga a la adoptada en el capitel jaqués (figs. 4-5). En Moraime, a diferencia de la representación de la catedral de Jaca, Daniel aparece representado dentro de la fosa; esta alusión figurativa a la fosa en la que fue introducido el profeta con los animales no es sólo una excepción en el territorio gallego, es también una imagen poco frecuente en la escultura medieval occidental. La valoración del elemento iconográfico en cuestión sigue una tradición de raíz paleocristiana que hemos podido rastrear en ciclos pictóricos y escultóricos fechados entre finales del siglo IV y comienzos del V: un buen testimonio lo encontramos en el programa pictórico de las catacumbas de Santa María delle Stelle -Verona-, el de la catacumba de los Jordani, o los frescos que decoran la cúpula de la Capilla de la Paz de El Bagawat en el oasis de Kargé -Egipto-. En todos ellos se muestra al profeta con los leones en el interior de una fosa sencilla de forma rectangular ${ }^{13}$. También se alude figurativamente a la fosa en una pequeña placa de marfil del siglo V ilustrada con la condena de Daniel y que se conserva actualmente en el Museo de Cartago ${ }^{14}$; igualmente, la encontramos en un fragmento de cancel del Museo Arqueológico de Estambul procedente de Thasos y de la misma época ${ }^{15}$. Este recurso iconográfico adquiriría también cierta popularidad en el repertorio de los ciclos escultóricos paleocristianos hispanos como muestran notables relieves funerarios de época constantiniana,

\footnotetext{
${ }^{13}$ Para la representación de Santa María de Stelle: Perraymond, M.: "Abacuc e il cibo soterico: iconografía e simbolismo", Studi e Materiali di Storia delle Religioni, 58, 1998, pp. 249-274, esp. p. 263, fig. 7; para el freco de la catacumba de los Jordani: Grabar, A.: The Beginnings of Christian Art, 200-395, New York, 1967, fig. 239; Shapiro, M.: Palabras, escritos e imágenes. Semiótica del lenguaje, Madrid: Ed. Encuentro, 1998, p.26, fig. 6. Para las pinturas de la Capilla de la Paz: Fakhry, A.: The Necropoli of El Basawat, Cairo, 1951, p. 74, fig. 65; Stern, H.: "Les peintures du Mouseleé de 1’Exode á El Bagaouat", Cahiers Archéologiques, 11, 1960, p. 119; Schlunk, H.: "Un relieve de sarcófago cristiano de Barba Singilia”, Archivo Español de Arqueología, 42, 1969, 119-182, pp. 166-182, esp. 181-182, fig. 8, Pijoán, J.: Arte cristiano primitivo. Arte Bizantino, en Summa Artis. Historia General del Arte, T. VII, Madrid: Espasa Calpe, S.A, 1974, pp. 45-51, esp. p. 45, fig. 49.

${ }^{14}$ Sobre esta pieza: Arbeiter, A.: 1994, pp. 5-12, esp. 9, Taf. 2,6.

15 Grabar, A.: Sculptures Byzantines de Constantinople (IV-X siécles), Paris: Libr. Andrè Maisonneuve, 1963, pp. 48, 129, fig. XVII, I; Pijoán, J.: Arte cristiano primitivo. Arte bizantino, en: Summa Artis. Historia General del Arte, vol. VII, Madrid: Espasa Calpe, S.A, 1974, p. 137, fig. 207; Firath, N.: La sculpture byzantine figurée au Musée Archéologique d'Istanbl, 1990, fig. 94; Arbeiter, A.: 1994, p. 10, Taf. 2,1.
} 


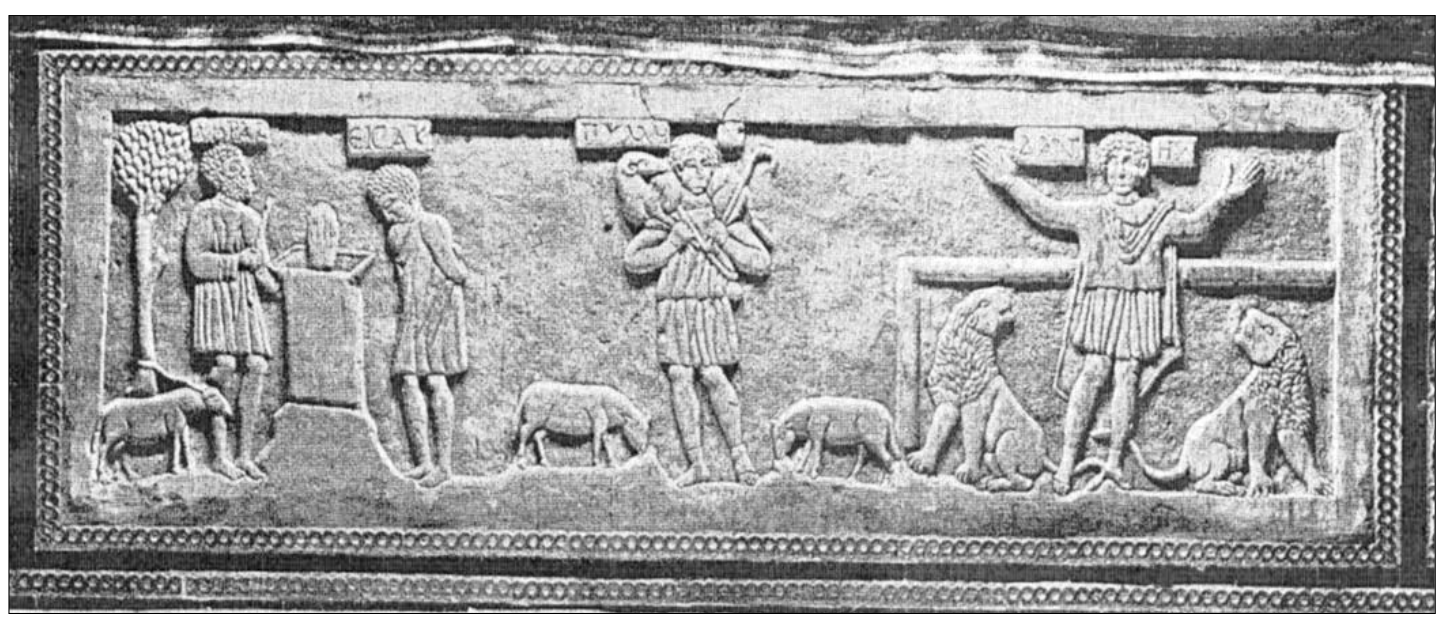

Figura 6. Relieve del sarcófago paleocristiano de Ecija [Fotografía: Schlunk, H.: 1962]

Figura 7. Fragmento del sarcófago paleocristiano de Alcaudete

[Fotografía: Schlunk, H.: 1962]

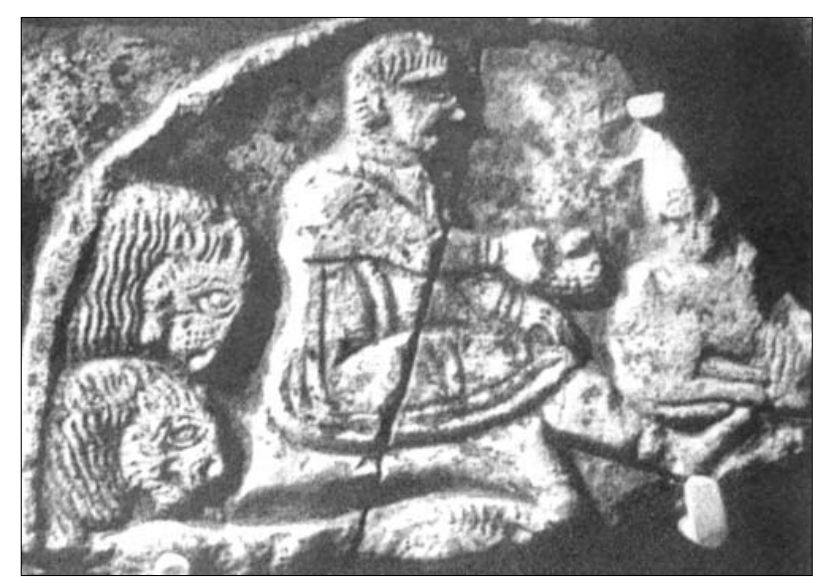

como el que decora uno de los laterales del sarcófago de Écija -Sevilla- Parroquia de Santa Cruz- o el de Alcaudete -Jaén- Museo Arqueológico Nacional de Madrid-16 (figs. 6-7). Este recurso figurativo irrumpirá en el ámbito de los manuscritos iluminados con cierta entidad a lo largo de la décima centuria perviviendo en el arte occidental hasta bien entrado el siglo XV. Así, algunos beatos hispánicos de finales del siglo $\mathrm{X}$ recogen ya esta tradición figurativa; como podemos reconocer en el ciclo figurativo que ilustra una de las páginas del Beato de Girona -Mus. Cat. Girona, $\mathrm{n}^{\circ}$ Inv. 7 (11), fol. 257 - año 975-, en el Beato de la Biblioteca Nacional de Madrid -Ms. Vit. 14-2, fol. 286 -siglo X- o en el Beato de la Seu d'Urgell -Mus. Dioc. de la Seu d’Urgell, nº Inv. 501,

\footnotetext{
${ }^{16}$ En el sarcófago de Écija podemos reconocer la imagen de Daniel introducido en el interior de la fosa, de forma rectangular y de gran simplicidad, vestido con una túnica corta y los pies desnudos, levantando los brazos en oración, entre dos leones. En el relieve de Alcaudete la composición alcanza un mayor grado de complejidad; Daniel se representa sedente, en el interior de una fosa de forma circular y con dos leones situados detrás de él. El relieve, que ha llegado hasta nuestros días mutilado, habría alcanzado, como propuso en su momento Helmut Schlunk, un mayor desarrollo y el episodio se complementaría con la escena de Habacuc transportado por el ángel hasta la fosa. Para ambos sarcófagos véase: Schlunk, H.: "Die Sarkophage von Ecija und Alcaudete", Madrider Mitteilungen, 3, 1962, pp. 119. 151, fig. 4,6 ; Arbeiter, A.: 1994, pp. 8-10, Taf. 1, 2,5. Sobre el sarcófago de Ecija: Fidel Fita.: "Sarcófago cristiano de Ecija”, Boletín de la Real Academia de la Historia, 10, 1887, pp. 267-273; para el sarcófago de Alcaudete: Recio, A.
} 


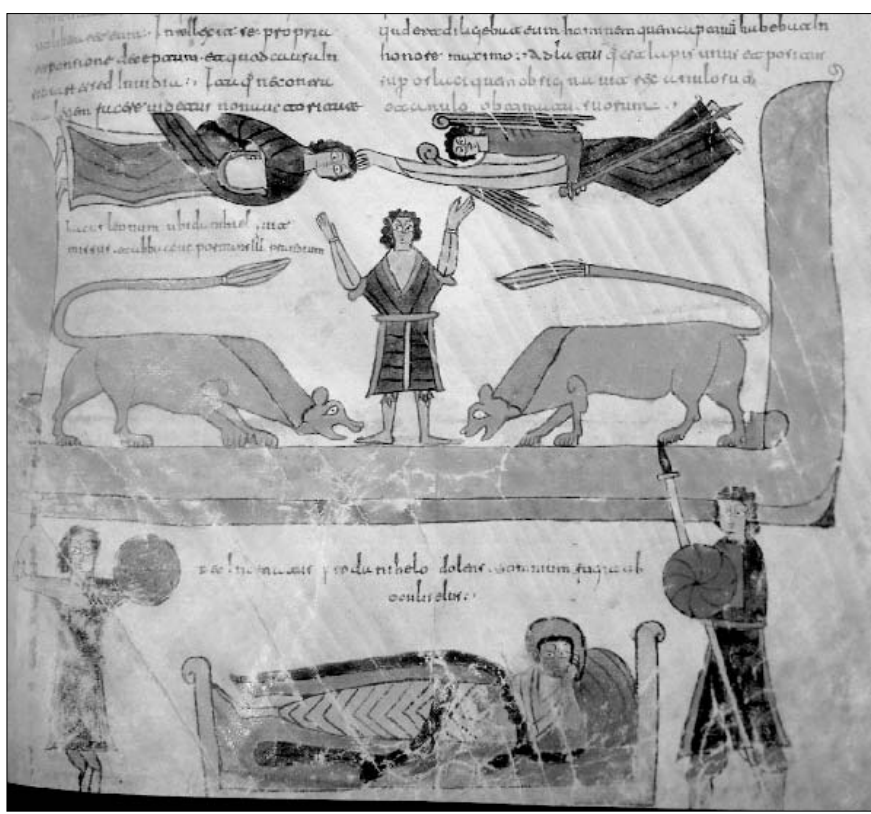

Figura 8. Beato de la Seu d’Urgell -Mus. Dioc. de la Seu d'Urgell, $\mathrm{n}^{\circ}$ inv. 501, fol. 210-

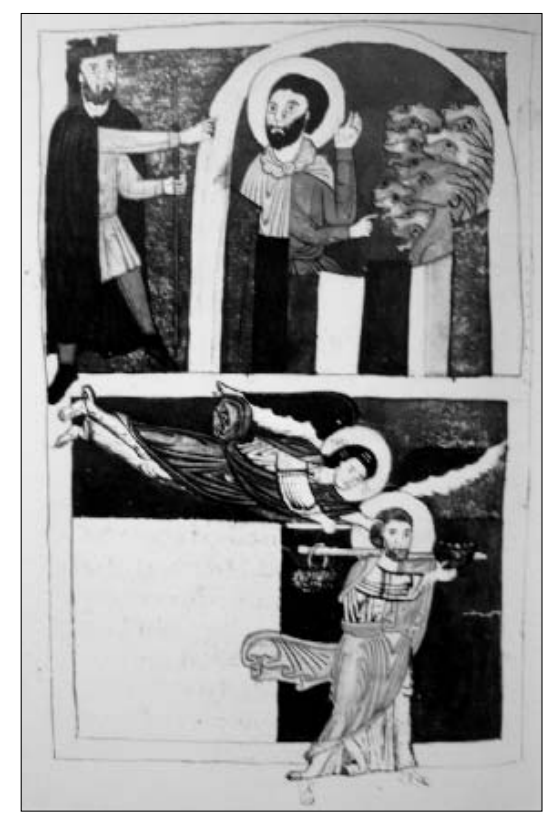

Figura 9. Biblia de la Catedral de Florencia - Bibl. Med. Laur, edili 125, fol. 259v.

fol. 210 -último cuarto del siglo X_17 (fig. 8); con todo, no será hasta época románica, y sobre todo a lo largo de los siglos XIV y XV, cuando alcance una mayor difusión y siempre en el ámbito de los ciclos miniados: así, en la Biblia catalana de San Pere de Rodes -París, BN Ms. Lat. 6, III, fol. 66v -último cuarto del siglo XI-, en uno de los capítulos que se ilustra con episodios del Libro de Daniel se figura la imagen del profeta en el interior de un sencillo habitáculo acompañado de las bestias ${ }^{18}$; de igual manera se rastrea en la Biblia románica de la catedral de Florencia -Florencia, Bibl. Med. Laur., edili 125, fol. 259v -comienzos del siglo XII- (fig.9) o en la alemana Michaelbeuern Bible -Michaelbeuern, Stiftsbib; Cod. Perg. 1, fol. 191 -segundo cuarto del siglo XII-19.

"Una tapa de sarcófago constantiniano hallada en Alcaudete", Antonianum, 43, 1968, pp. 109-112; Fontaine, J.: La España Románica. El prerrománico, Madrid: Ediciones Encuentro, 1982, figs. 22-24; Vidal Álvarez, S.: 2002, pp. 220-238, Taf. 27, a y b.

17 Neuss, W.: Die katalanische Bibelillustration um die Wende des ersten Jahrtausends und die altspanische Buchmalerei, Bonn: verlag Kurt Schroeder, 1922, figs. 52-53; Schlunk, H.: 1945, figs. 3-5.

${ }^{18}$ Neuss, W.: 1922, fig. 102; Schlunk; H.: 1962, p. 142, fig. 6; Walter, C.: 1982, p. 75, fig. 46.

19 Walter, C.: 1982, pp. 152, 156, figs. 110, 113. Respecto a las Biblias de época gótica, podemos citar el Libri Prophetarum de la Biblia de Suabia - Weingarten (Bibl. Public. de San Petersburgo, Lat. V, v.I.133, fol. 105r-ca 1220) Swarzenski, H.: La Sagrada Escritura de Weingarten Abbey, Nueva York, 1943, pp. 102-103, figs. L-LIV; Voronova, T y Sterligov, A.: Manuscritos iluminados de Europa Occidental. De los siglos VIII a XVI, Reino Unido: Parkstone Press/Aurora, 1998, p. 298, fig. 299; en la Biblia de Angers (Angers, Bibl. Mun .- año 1225), en el capítulo del Libro de Daniel contenido en el primer libro del Livre du Trésor de Brunetto Latini (Bibli. Nat. de Rusia, Fr. F.v. III.4, fol. 18r-ca. 1310-1320), Voronova, T y Sterligov, A.: 1998, p. 55, fig. 56] (fig. 10); en dos de las Biblias góticas de Tours conservadas en la Biblioteca Nacional de París datadas respectivamente en el año 1200 y 1315, en una de las iniciales del ciclo miniado de la Biblia de la Bodleian Library (Bodleian Library, Ms. Lat. Bib. e. 7, fol. 289r - primera mitad del siglo XIII-; en el ciclo del Libro de Daniel del Salterio de la Haya (Bibli. Nat. Libr. Netherland- siglo XIV),También en una de las iniciales historiadas de la Biblia de la abadía de San Sulpicio de Bourges ilustrada en el siglo XIV y en otros manuscritos iluminados del siglo XV como el Hrvoj Vukcic Hrvatinic Missal (Topkapi Sarayl Museum de Estambul), y en la historia de Joseph, Daniel, Judith y Esther ilustrada en el año 1462 en Bamberg por Albrecht Pfister (John Rylands University Library). 


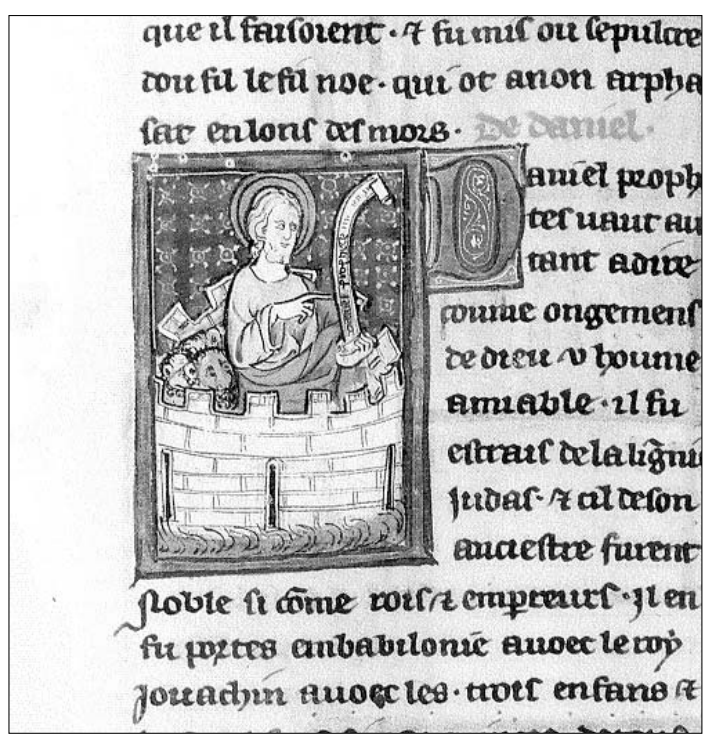

Figura 10. Livre du Trésor de Brunetto Latini (Bibli. Nat. de Rusia, Fr. F.v. III.4, fol. 18r).

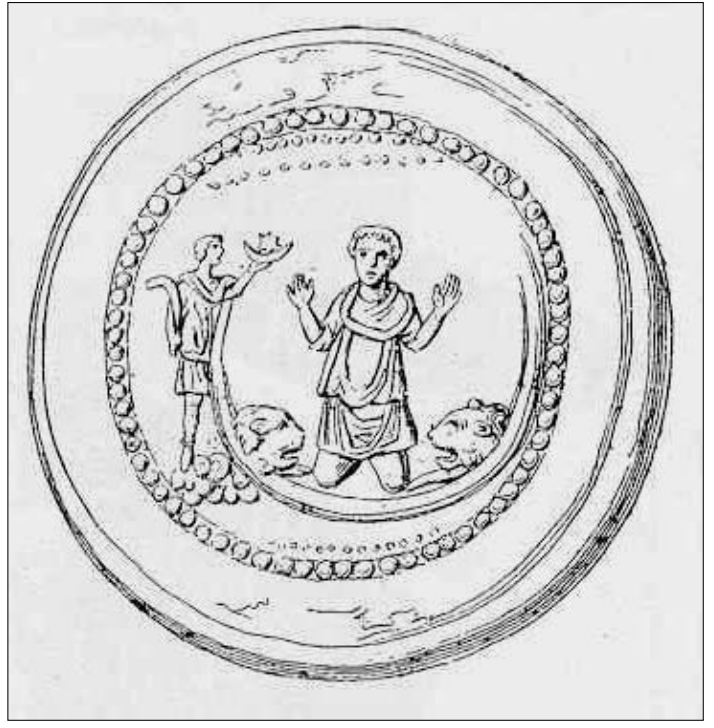

Figura 11. Medallón con el tema de Daniel en el foso de los leones [Fotografía: Cabrol, F; Leclercq, H.: 1925].

La fortuna alcanzada en los ciclos miniados medievales contrasta con la escasa entidad que adquiere en los programas escultóricos. Ciertamente, el episodio de la portada coruñesa sólo encuentra parangón en la portada de Santa María de Ripoll, aunque aquí Daniel y los leones están encajados en el interior de una sencilla fosa cuadrada que nada tiene que ver con la de Moraime, donde el foso adquiere los rasgos de un edificio con una pequeña galería de doble arcada de medio punto en su frente ${ }^{20}$.

Si la particular concepción que se ha dado en Moraime al tema cuenta con precedentes en la portada jaquesa, al mismo horizonte parecen remitir otros detalles iconográficos: Habacuc lleva en una de sus manos un objeto redondo, que sin duda ha de interpretarse como el pan para alimentar al profeta, y en la izquierda esgrime un útil que nos resulta totalmente enigmático: una especie de bastón. Ciertamente, este atributo determina una caracterización un tanto original para la imagen de Habacuc, y naturalmente desconozco hasta qué punto la complementariedad de este atributo posee un valor iconográfico. Obviamente, el significado de este complemento queda relacionado con otras equivalencias que no forman parte de la exégesis tradicional. Moralejo ya había recalcado en su día lo insólito de la presencia de este objeto que también porta en sus manos uno de los personajes, que el historiador ha sugerido interpretar como una duplicidad de la imagen de Habacuc, en el episodio del capitel de la portada jaquesa ${ }^{21}$. Entre los precedentes aducidos por el historiador destaca un medallón de finales del siglo IV conservado en el Museo Vaticano en el que Habacuc, de pie y al lado de la fosa, lleva en su mano izquierda los alimentos y en la derecha una especie de cayado corto 22 (fig. 11). También, uno de los capiteles del arco toral del ábside de la Epístola de la Catedral de Lescar se figuraba a Habacuc portando los alimentos en una cesta que cuelga de un bastón ${ }^{23}$. En uno de los capítulos del Libro de Daniel de la Biblia iluminada de Sancho el Fuerte de Navarra -de comienzos del siglo XIII y conservada en Amiens -Amiens.

${ }^{20}$ Melero Moneo, M.: 2003, 141-142, fig. 6.

${ }^{21}$ Moralejo Álvarez, S.: 1977, pp. 183-184, fig. 1;

22 Ídem.: p. 184, not. 33. Sobre este medallón véase: Cabrol, F. y Leclercq, H.: 1920, p. 245, nº 3590.

23 Moralejo Álvarez, S.: 1977, not. 33. Sobre el capitel véase también Gómez Moreno, M.: 1934, lám. LXXXI. 
Bibli. Communale, Ms. lat 108, fol. 104v- Habacuc, anciano y barbado, sostiene en su mano derecha la cesta con los alimentos y con la izquierda se apoya en un bastón en forma de tau ${ }^{24}$. Sin duda, nos podríamos encontrar con distintas justificaciones para la presencia de este motivo.

Desde el punto de vista iconográfico, la inclusión de la condena de Daniel en un programa de portada como el de San Xulián de Moraime revela una clara intencionalidad por parte del mentor del programa de proyectar y reforzar la significación del tímpano de la portada en cuya cara externa se representa la Última Cena y en la interior la imagen del Cordero en un clípeo sostenido por ángeles ${ }^{25}$. Con la presencia de Daniel con Habacuc y el ángel entran en escena nuevos elementos que ya en la exégesis cristiana primitiva redundaron en una interpretación de sentido cristológico y eucarístico; el hecho de permanecer en un foso precintado y resucitar al séptimo día del proceso, prefiguración de la muerte y la resurrección de Cristo, será reforzado en sentido eucarístico, plásticamente explícito, por medio de la representación de los alimentos que Habacuc ofrece al profeta. Por otro lado, se subraya la metáfora del sostén espiritual, quizá para reafirmar la doctrina de la presencia divina, y la victoria de Daniel se equipara a la victoria de las almas fortalecidas por el sacramento en su lucha perpetua contra el pecado. Subyacen en esta portada ciertos planteamientos de carácter moralizante relacionados con los atributos del profeta, cual exemplum, frente a la debilidad de la condición humana y los pecados que nos rodean, a los que se alude figurativamente en los capiteles contiguos mediante la imagen de metáforas animales de carácter moralizante procedentes de los bestiarios medievales, como los sagitarios o los leones atados por lías, y de manera más implícita en la representación del Pecado Original.

A diferencia de Moraime, en los episodios de la condena de Daniel (14, 27 y ss) que se representan en el interior de la catedral de Mondoñedo ${ }^{26}$ y en la portada del templo de Santiago de A Coruña, el artista se ha mantenido fiel a la composición universalmente aceptada para la enunciación plástica del episodio desde mediados de la duodécima centuria y que inaugura el ciclo iluminado del Beato de Saint-Sever-Bibl. Nat. de París, Ms. lat. 8878, fol. 233 ${ }^{\mathrm{v}}-$, en el que se muestra a Daniel de perfil y sentado con siete leones ante él, incluyendo la asistencia de Habacuc, milagrosamente transportado para llevar el pan a Daniel ${ }^{27}$ (fig. 12). La representación sedente, nueva en esta escena, se basaba en uno de los pasajes de la Biblia (Dan 14, 39-40) ${ }^{28}$ que hasta la fecha había sido ignorado por los artistas y en el que se relata cómo El rey vino el día séptimo para llorar a Daniel. Llegó al foso y miró, y he aquí que Daniel estaba sentado, así como la referencia a los siete leones que acompañaban al profeta (Dan 14, 32) ${ }^{29}$.

$$
* * *
$$

La fortuna que el episodio alcanzó en los ciclos figurativos románicos de nuestra región queda nuevamente reflejada en el programa que ilustra el interior de la cabecera del templo de Santo Tomé de Piñeiro -Marín, Pontevedra-; sin embargo, el tratamiento que recibe aquí no encuentra

\footnotetext{
24 Bucher, F.: The Pamplona Biblies, T. I, New Haven and London: Yale University Press, 1970, p. 35, plate. 326.

25 Sousa, J.: 1983; Sánchez Ameijeiras, R.: "Algunos aspectos de la cultura visual en la Galicia de Fernando II y Alfonso IX" en: Románico en Galicia y Portugal, Ed. Fundación Pedro Barrié de la Maza, A Coruña, 2001, pp. 157-183, esp. p. 158-159.

26 Para el episodio de la Catedral de Mondoñedo: Castro Fernández, C.: 1993, pp. 52-53, figs. 52-54, 57, pp. 114115,118

${ }^{27}$ Neuss, W.: 1922, fig. 51; Schlunk, H.: 1962, p. 141, abb. 5.

28 "Y levantándose Daniel comió. Y el ángel de Dios restituyó a Habacuc al instante a su lugar. El rey vino el día séptimo para llorar a Daniel. Llegó al foso y miró, y he aquí que Daniel estaba sentado" (Dan 14, 39-40); Bover, J.Ma y Cantera Burgos, F.: Sagrada Bíblia. Versión crítica sobre los textos hebreo y griego, T. II, Madrid: Biblioteca de Autores Cristianos, 1948, p. 1609.

29 "Habían en el foso siete leones, y les daban cada día dos cuerpos humanos y dos ovejas; pero entonces no se los dieron, para que devorasen a Daniel" (Daniel, 14, 32); Ibídem, p. 1608.
} 


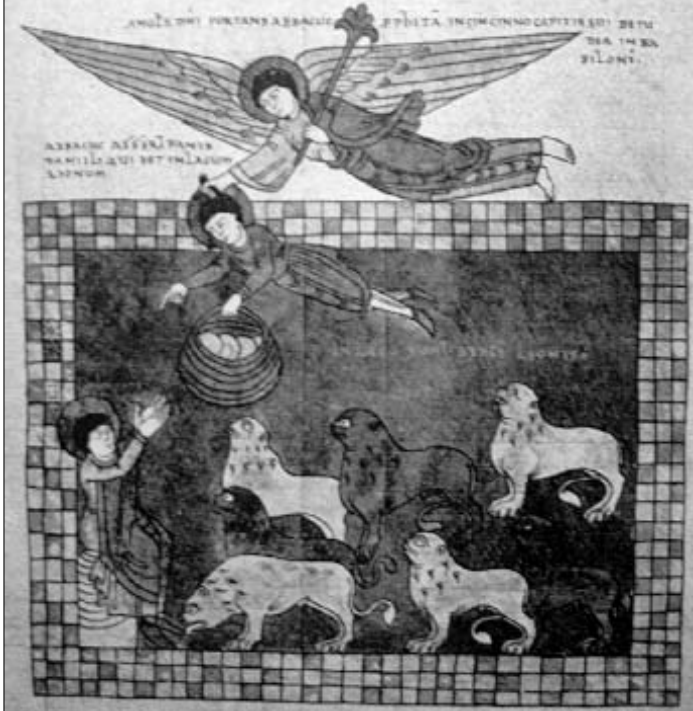

Figura 12. Beato de Saint-Sever -Bibl. Nat de París, Ms. Lat 8878 , fol. 233v.

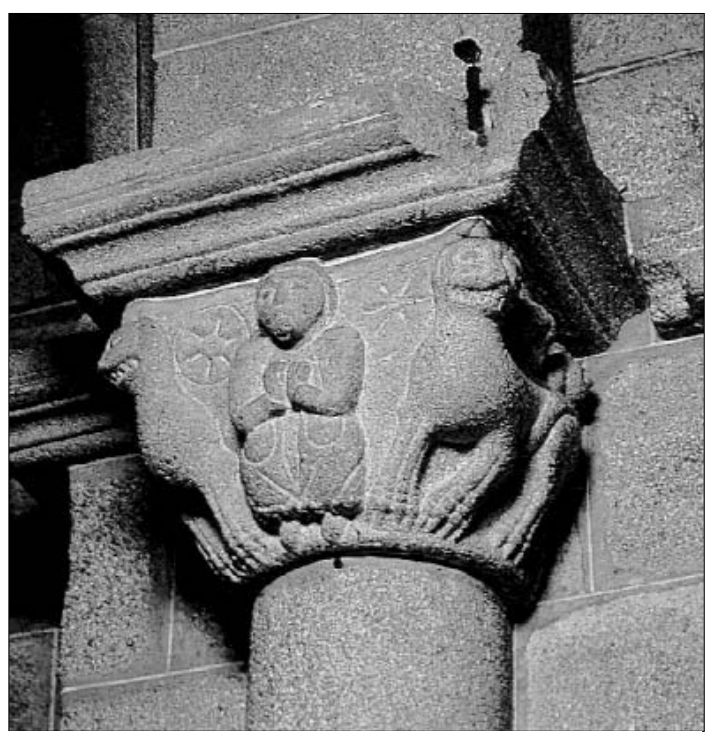

Figura 13. Capitel del interior de la cabecera del templo benedictino de Santo Tomé de Piñeiro.

paralelos en ninguno de los precedentes citados ${ }^{30}$. El tema, poco esperado en el contexto en el que se ubica, ha pasado desapercibido hasta la fecha a causa de lo anómalo de su figuración: en uno de los capiteles del arco triunfal se talló la imagen de Daniel manteniendo la disposición más común, de corte heráldico, frontal, con las manos alzadas en actitud de orante y flanqueado por dos leones dispuestos en estricta simetría (fig. 13). Una primera lectura puramente objetiva nos permitiría evocar la primera condena de Daniel como la interpretación más probable. Sin embargo, un análisis más riguroso del programa figurativo que ilustra el resto de los capiteles de la cabecera nos revela otras intenciones. En efecto, la escena figurada en el capitel derecho del arco toral nos invita a dudar de la primera interpretación: a primera vista, la escena en cuestión parece evocar la asistencia divina prestada por mediación de Habacuc y el ángel como la interpretación más probable: en el lateral del capitel que queda oculto al espectador se representa a un ángel volando que lleva sujeto por los brazos a una figura que porta en una de sus manos un objeto redondo (figs.14-15). No obstante, la representación viene determinada por una fórmula un tanto anómala para el suceso en cuestión: desde el punto de vista compositivo la representación se muestra un tanto desequilibrada, ya que se observa un significativo desplazamiento del asunto principal -Habacuc con el ángel-, a una de las caras laterales del capitel, en contraste con el desconcertante protagonismo concedido a los dos leones que centran la cara principal y al ángel que se dispone en el lateral más visible (fig.16). Se trata de un planteamiento en su conjunto que es difícil de justificar, pero en él, a todas luces, se puede adivinar una alusión figurativa a la segunda condena.

30 Para Santo Tomé de Piñeiro: Sá Bravo, H: El Monacato en Galicia, vol. II, A Coruña: Editorial Librigal, 1972, pp. 232-235; Idem, Las rutas del Románico en la provincia de Pontevedra, Vigo: Ed. Caja Rural Provincial de Pontevedra, 1978, pp.162-163; Bango Torviso, I.G.: Arquitectura románica en Pontevedra, A Coruña: Fundación Pedro Barrié de la Maza, 1979, lám. LXXXVII, b) y f); Yzquierdo Perrín, R.: 1993, p. 340; Fontoira Suris, R.: Inventario de la Riqueza Monumental de la Provincia de Pontevedra y el Camino de Santiago, Pontevedra: Excma. Diputación Provincial de Pontevedra, 2002, pp. 300-301; Moure Pena, T.C.: "Daniel no foxo dos leóns" no programa escultórico de San Tomé de Piñeiro (Marín, Pontevedra", Aunios, Especial Xacobeo 2004, nº 9, pp. 21-26. 

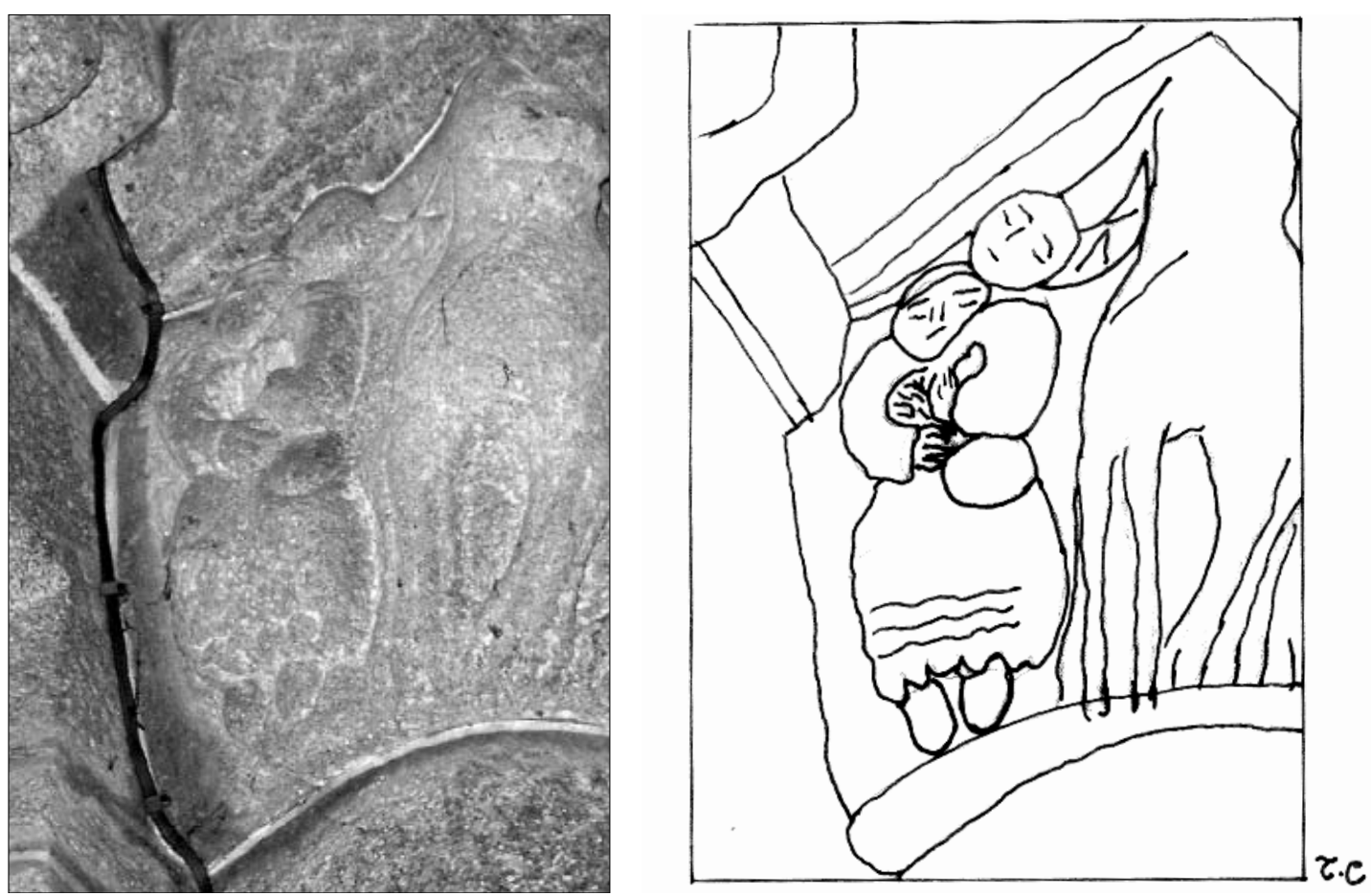

Figuras 14-15. Capitel del interior de la cabecera del templo benedictino de Santo Tomé de Piñeiro[Dibujo: autora].

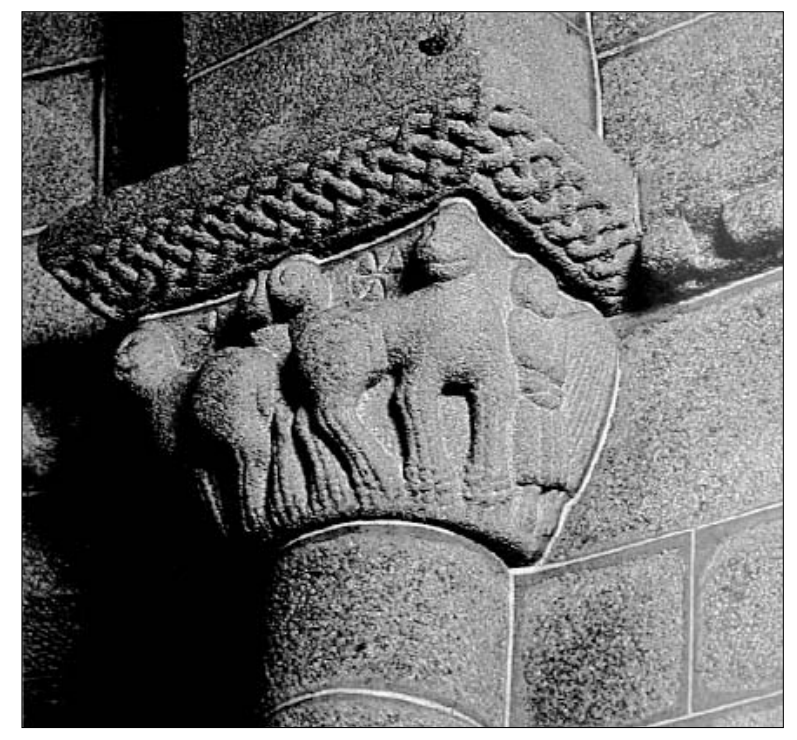

Figura 16. Capitel del interior de la cabecera del templo benedictino de Santo Tomé de Piñeiro. 
No cabe la menor duda de que esta formulación narrativa del episodio resulta atípica en los programas escultóricos occidentales, en los que se suele respetar la tradicional composición del tema basada en la rigurosa disposición de Daniel en la cara principal del soporte flanqueado por los leones y Habacuc y el ángel relegados a un segundo plano, normalmente a las caras laterales. ¿Por qué se diseñó el tema de semejante manera?, ¿Posiblemente a causa de la impericia del propio escultor en la adaptación del tema al soporte?, ¿o tal vez responda a una intencionalidad?. Resulta difícil de determinar. En cualquier caso, nos consta que en algunos templos románicos burgaleses ya se había ensayado alguna experiencia similar: podemos reconocer una solución muy parecida en el episodio de la primera condena que figura en el exterior de la cabecera de San Pedro de Tejada, en donde en uno de sus capiteles aparece representado Daniel entre los leones que devoran a los enemigos del profeta, mientras que en el capitel contiguo se plasma la imagen del ángel enviado por Dios para cerrarle la boca a los leones; de igual manera, esta extraña formulación narrativa la encontramos ilustrando una de las páginas de la Biblia de Sancho el Fuerte de Navarra (1194-1234); aquí, en la escena superior aparece Daniel sentado entre seis leones, mientras que en la inferior se representa el momento de la asistencia física de Habacuc ${ }^{31}$.

Sin posible interpretación satisfactoria quedaría un personaje que se encuentra en la cara lateral -la visible- al lado de un león. Es de notar que su presencia es relativamente extraña y poco esperada en el contexto en el que figura, lo que nos obliga a actuar con prudencia a la hora de ofrecer una lectura iconográfica. Sin duda, su presencia y significado pueden estar justificados por múltiples equivalencias; a título de hipótesis, una primera interpretación nos permitiría pensar en una posible duplicación de la imagen del profeta Daniel. Pero esta interpretación choca con un rasgo básico: la presencia de las alas, algo que no es consustancial a la imagen del profeta. Entiendo que la complementariedad de las alas comprometería la lectura propuesta, si bien no estará de más recordar que en el episodio de Daniel entre los leones que ilustra uno de los capiteles del interior de la cabecera del templo monástico de San Salvador de Ferreira -Ferreira de Pantón -Lugo-, y en uno de los de la cabecera del templo aragonés de San Salvador de Majones, Daniel aparece provisto de amplias alas ${ }^{32}$. Sin embargo, es precisamente la presencia de las alas lo que me hace pensar si no habrá que conceder otros valores significativos a la imagen. En relación con esto, no me parecería en modo alguno ilegitima su identificación con el ángel enviado por Dios para cerrar la boca a los leones al que alude Daniel 6, 22 parangonando la representación de San Pedro de Tejada 33 . Aunque no ignoramos que este episodio en cuestión se asocia con la primera condena del profeta, no resultaría en absoluto inadecuada su presencia en este ciclo si admitimos, como ha apuntado Moralejo, que gran número de las soluciones híbridas que caracterizan este tema iconográfico son consecuencia de las continuas interferencias entre elementos de ambas condenas ${ }^{34}$. Esta interpretación me parece la más coherente a la hora de formular el significado último de la imagen

31 Bucher, F.: 1970, p. 35, plate. 326.

32 Para el capitel de la cabecera de San Salvador de Ferreira, véase los siguientes trabajos: Enríquez Flórez, Ma. F.: "El Real Monasterio de Santa María de Ferreira de Pantón", Cistercium, XXXVI, 1976, pp. 125-159; Idem, "A escultura medieval na igrexa do mosteiro cisterciense do divino Salvador de Ferreira de Pantón, Lugo", en: Monasticum, 1999, pp. 189-121; Yzquierdo Perrín, R.: "La iglesia del monasterio cisterciense de Ferreira de Pantón", Actas del Congreso Internacional sobre San Bernardo y el Císter en Galicia y Portugal, II, Ourense, 1991, pp. 854-875; Yáñez Neira, D. y Tobío Cendón, R.: Ferreira de Pantón. Monasterio cisterciense en la Ribeira Sacra, León: Ed. Edilesa, 2000, p. 28; Moure Pena, T.C., 2001, pp. 68-69, figs. 47-48. Para el capitel de San Salvador de Majones, véase: Cobreros, J.: Itinerarios románicos por el Alto Aragón, Madrid: Ediciones Encuentro, 1989, lám 61.

33 "Mi Dios ha enviado a su ángel y ha cerrado la boca de los leones y no me han causado mal alguno, por cuanto he sido hallado inocente ante Él, y tampoco ante ti joh rey; he cometido maldad alguna" (Dan. 6,22); Bover, J.M ${ }^{a}$ y Cantera Burgos, F.: 1948, p. 1594.

${ }^{34}$ Moralejo Álvarez, S.: 1977, p.182. 
del ángel, que con su presencia al lado de Habacuc estaría reafirmando la metáfora del sostén espiritual.

Entre las dos escenas ilustradas en la cabecera de Santo Tomé de Piñeiro existe una relación incuestionable: el capitel del arco triunfal ha de entenderse como un signo y preparación de lo que ha de venir, plasmado figurativamente en el del arco toral. Esta secuencia de sucesos aislados son signos inteligibles sólo para un lector creyente, para una audiencia específica conocedora del plan histórico en el que tanto la condena como su culminación, con la representación metafórica del sostén espiritual reafirmando la doctrina de la presencia divina, surge de la voluntad de Dios. Al mismo tiempo, se ensalza la victoria de las almas fortalecidas por el sacramento en su lucha perpetua contra el pecado, al que aluden las máscaras grotescas que vomitan lías y que aparecen representadas en el capitel contiguo.

La presencia del profeta Daniel adquiere entonces una nueva dimensión en la consideración global del programa escultórico en el que se inserta, en el que se denota un discurso moral de claras connotaciones invocativas. En la primitiva liturgia cristiana abundaban los rituales donde se imploraba el poder salvador de Dios, en las plegarias individuales, en las oraciones bautismales o de la propia vigilia pascual se enumeraba un grupo de personajes que gracias a la intervención divina se habían salvado del mal, del peligro y de la muerte, entre ellos a Daniel. La invocación ¡Salva me ex ora leonis! incluida en estas plegarias convirtió al profeta en uno de los primeros referentes invocativos del cristiano que esperaba con su rogativa que Dios ejerciese su indulgencia.

La pervivencia a lo largo de la Edad Media de todo este tipo de plegarias y la interpretación que adquirió la imagen del profeta Daniel sirve para explicar el notable porcentaje de frecuencias del tema desde mediados del siglo XII en los programas figurativos de las cabeceras de un amplio número de templos románicos en los que se asocia simbólica y figurativamente el episodio del profeta Daniel con imágenes moralizadoras procedentes de los repertorios de los Bestiarios medievales o a imágenes de pecadores. Baste recordar aquí el repertorio de la cabecera de San Salvador de Ferreira de Pantón, donde se evidencia un planteamiento iconográfico similar ${ }^{35}$; lo mismo se aprecia en Santa María de Bermún -Chantada, Lugo-36, en San Pedro de Rebón -Moaña, Pontevedra-37, en Santa María de Bermés -Lalín, Pontevedra-38 y, desde fechas más tempranas, en la cabecera de la abacial benedictina de San Bartolomeu de Rebordáns -Tui, Pontevedra-.

$$
* * *
$$

35 Enríquez Flórez, Ma. F.: 1976, pp. 125-159; Idem, 1999, pp. 189-121; Yzquierdo Perrín, R.:1991, pp. 854-875; Yáñez Neira, D y Tobío Cendón, R.: 2000, p. 28; Moure Pena, T.C.: 2001, pp. 68-69, figs. 47-48.

36 Yzquierdo Perrín, R.: La arquitectura románica en Lugo, La Coruña: Fundación Pedro Barrié de la Maza, 1983, pp. 39, 255 .

37 Bango Torviso, I.G.: 1979, lám. LXXXIX, a) y XC, d); Sá Bravo, H.: 1978, p. 432; Idem, “Caldas de Reis. Páginas históricas de la villa y de linajes de la misma y su contorno”, El Museo de Pontevedra, T. XXXVIII, 1984, pp. 259261, lám. XLVI a).

38Bango Torviso, I.G.: 1979, lám. IX j); Idem, “Aportaciones a una catalogación de la imaginería gótica de Pontevedra”, El Museo de Pontevedra, T. XXXII, 1978, pp. 95-104; Idem, 75 obras para 75 años. Exposición Conmemorativa da Fundación do Museo de Pontevedra, Pontevedra, 2003, p. 230, nº 18; Carrillo Lista, Mª.P; Ferrín González, J.R., 1997, p. 73; Yzquierdo Perrín, R.: “La iglesia románica de Santa María de Bermés”, El Museo de Pontevedra, T. XXXII, 1978, pp. 85-94; Idem, 1976, p. 9. Los capiteles de Santa María de Bermés se conservan actualmente entre los fondos del Museo Provincial de Pontevedra. Recientemente, Bango Torviso se cuestionó la identificación del protagonista de la escena con la condena de Daniel ya que la imagen no parece ajustarse a la caracterización tradicional del profeta: en el capitel de Bermés el personaje se representa desnudo, por lo que el historiador ha sugerido la posibilidad de que nos encontremos ante la representación del alma del cristiano triunfando ante la muerte. Sin embargo, debemos mantener una duda razonable sobre tal interpretación ya que, como es sabido, la iconografía paleocristiana, respondiendo a una tipología de tradición clásica, nos presenta a Daniel desnudo entre las bestias. El episodio fue perdiendo gradualmente su apariencia clásica a lo largo de los siglos XII y XIV lo más tardar, por lo que no sería extraño, aunque sí poco habitual, 


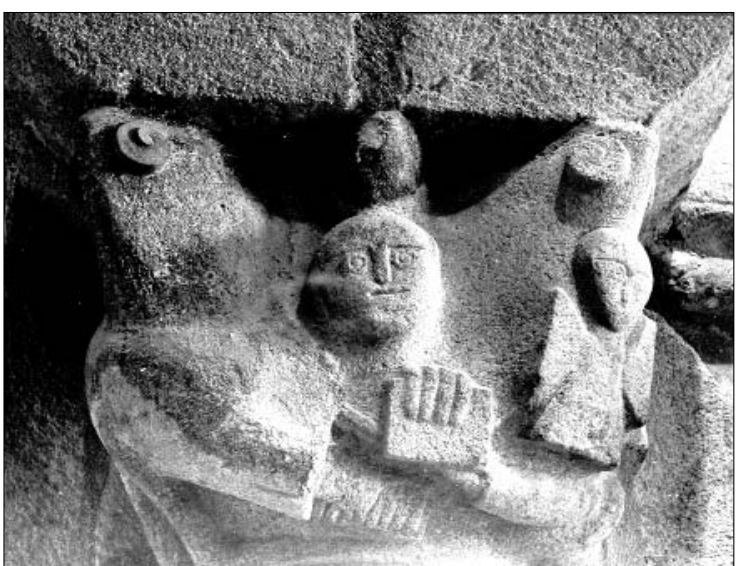

Figura 17. Capitel de la capilla meridional del templo benedictino de San Bartolomeu de Rebordáns.

Figura 18. Capitel de la capilla meridional del templo benedictino de San Bartolomeu de Rebordáns.

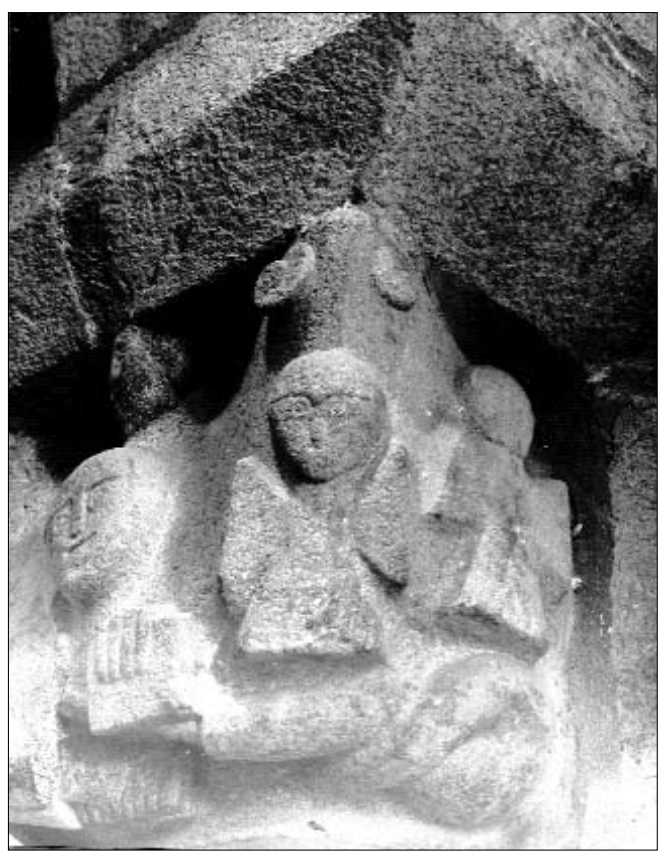

Vamos a centrarnos en la representación que del mismo tema se exhibe uno de los capiteles de la capilla meridional de la cabecera de San Bartolomeu de Rebordáns. La identificación de la condena del profeta Daniel parece incuestionable, ya que a él alude la figura central: de pie, ataviada con larga túnica, portando un libro cerrado en su mano izquierda, y flanqueada a su derecha por un león que le lame los pies ${ }^{39}$ bajo los cuales se distingue una gran serpiente, algo relativamente extraño, lo mismo que los ángeles de pequeñas dimensiones que ocupan respectivamente una de las esquinas y la cara lateral del soporte (figs. 17-18). En una primera lectura, la escena parece resumir el episodio narrativo completo del pasaje del Libro de Daniel en el que se relata la segunda dammatio sufrida por el profeta; en virtud de la identificación propuesta, la presencia de estas particularidades, aunque desorienten a primera vista por su infrecuencia, no constituyen en modo alguno excepción en la tradición iconográfica del episodio; debemos recordar que entre los hechos del profeta se encuentra el haber dado muerte a la serpiente o dragón sagrado al que rendían culto los babilonios (Dan 14, 23-27) dándole a comer una galleta compuesta por una indigesta mezcla de pez, hollín y cera, y que ésta fue precisamente la causa por la que sufrió una nueva

que en algunos ejemplos el artista se hubiese mantenido fiel al prototipo escultórico clásico; de hecho, en un capitel románico perteneciente al monasterio de Sant Serni de Tavérnoles (Anserral, Alt Urgell), que forma parte actualmente de la colección Jaume J. Arnal, y catalogado iconográficamente como una representación de Daniel entre los leones, podemos reconocer una representación que curiosamente presenta sorprendentes coincidencias con la del capitel de Bermés: Daniel barbado, desnudo y de pie, aleja de sí con sus manos las cabezas de dos leones dispuestos a ambos lados; Barrachina i Navarro, J.: "Capitell de Tavérnoles", en Catalunya Románica. T. XXVI. Tortosa i les Terres, Barcelona: Enciclopédia Catalana, 1997, p. 346. Junto con los ejemplos arriba citados, la plástica románica nos ha dejado otros ejemplos en los que se representa la condena de Daniel y que, sin estar en asociación figurativa con representaciones de pecadores o de imágenes demoníacas, son cita obligada; así, la representación que figura en uno de los capiteles de la cabecera de Santiago de la Pradera (Carballedo, Lugo), el de Santa Cruz de Viana (Chantada, Lugo), o la excepcional representación que figura en uno de los capiteles del triforio norte de la Catedral de Santiago. Para los capiteles lucenses, véase: Yzquierdo Perrín, R.: 1983, pp. 258, 267. Para el capitel compostelano, Idem, 1993, p. 224.

39 Sobre este capitel, véase: Bango Torviso, I.G.: 1979, lám. CXVIII, i) -j); Yzquierdo Perrín, R.: 1993, T. X, p. 189. 
condena ${ }^{40}$. Este episodio, que alcanzó cierta popularidad en los repertorios de los sarcófagos funerarios de época paleocristiana, fue ignorado en los programas figurativos románicos ${ }^{41}$. Precedentes del tema se documentan en el ciclo del frontal del llamado Sarcófago de Abraham y Daniel del Museo Lapidario de Arlés, en el Sarcófago de Jonás conservado en el mismo museo -ambos fechados en el siglo IV dC-, y en la lipsanoteca de Brescia del siglo V. En un fragmento de cuenco de vidrio inciso de época paleocristiana, importado con toda probabilidad de Italia y hallado en las excavaciones realizadas en la plaza de la Almoina de Valencia, en el que se representa una Traditio Legis y una orante entre figuras masculinas, figura también una posible escena de Daniel con la serpiente ${ }^{42}$. En el ámbito del arte medieval hispano únicamente conozco un caso en que se aluda a este episodio: el ciclo ilustrado de la Biblia catalana de San Pere de Rodes -París, BN Ms. Lat. 6, III, f. $66^{\mathrm{R}}-$ en la que en un mismo folio nos encontramos con una secuencia narrativa en la que se sucede la muerte del ídolo, la condena y el auxilio de Habacuc ${ }^{43}$. Pero volvamos al capitel de Rebordáns, ya que nos queda por abordar otra cuestión que desorienta: la imagen de los dos ángeles. Obviamente, la formulación resulta un tanto anómala. A mi juicio, no sería arriesgado proponer la identificación de ambos personajes con Habacuc y el ángel; la interpretación no me parece en modo alguno inadecuada ya que, aunque partimos del hecho básico de que la presencia de las alas no es algo consustancial a la imagen de Habacuc, debemos mencionar que en algunas representaciones tardoantiguas orientales Habacuc sí aparece caracterizado como un ángel; de esta manera lo encontramos representado en un fragmento de cancel procedente de Thasos conservado en el Museo Arqueológico de Estambul y fechado en torno al año 400 d.C ${ }^{44}$.

En Rebodáns, Daniel se yergue con la fuerza de la verdadera fe aplastando a las fuerzas del mal y exhortando a la lucha contra las creencias malignas. Él es la imagen del buen cristiano respetado por los leones y reconfortado por Habacuc por haberse resistido a dar culto a la serpiente y haberla vencido; visualizamos así su rechazo y dominio sobre el reptil al igual que el buen cristiano debe rechazar y dominar sus pasiones. Su imagen es testimonio de la fe profunda y exaltación del principio de la perfección cristiana, valores éstos a alcanzar no sólo por los que viven fuera de la comunidad sino, muy especialmente en función de su localización en este ámbito específico de la cabecera tanto aquí como en Santo Tomé de Piñeiro, por la reducida elite de aquellos que habían comenzado a ascender en la escala de la perfección, en alusión al ideal de vida al que la comunidad debe aspirar. En este contexto monástico benedictino, Daniel representa el comportamiento edificante mediante la práctica de la fe en Dios, de la humildad, la honestidad y la justicia, lo que no debe sorprendernos ya que se consideraban entre las principales virtudes a practicar por la audiencia a la que iba destinado el programa.

$$
* * *
$$

\footnotetext{
40 "Y había un dragón grande, y lo veneraban los babilonios. Y dijo el rey a Daniel: No podrás decir que éste no es un dios viviente. Adórale pues. Y dijo Daniel: Al Señor mi Dios adoraré, porque Él es Dios viviente. Y tú, ¡oh rey!, dame licencia y mataré al dragón sin espada ni vara. Y dijo el rey: Tela doy. Y tomó Daniel pez, grasa y pelos; los coció juntamente e hizo unas bolas y las dio a la boca del dragón. Y habiéndolas tragado, el dragón reventó. Y dijo: Mirad lo que adorais" (Dan14-23-27); Bover, J.Mª y Cantera Burgos, F.: 1947, T. II, p. 1608.

41 Sobre este episodio véase el estudio de Schneider, J.: Daniel und der Bel zu Babylon, Zeits, f. Schweizer, Archeologie und Kuntgeschichte, Basilea, 1954.

${ }^{42}$ Soriano, R.: L'arqueologia cristiana en la ciudad de Valencia: de la leyenda a la realidad, 1990, pp. 22-23; Eadem, "Los restos arqueológicos de la sede episcopal valenciana" en: IV Reunió d’Arqueologia Cristiana Hispánica, Lisboa, 1992, (1995), pp. 133-140.

43 Neuss, W.: 1922, Tf. 34, fig. 102; Castiñeiras González, M.A.: 2002, pp. 293-334, esp. P. 295-295, fig.5.

${ }^{44}$ Sobre esta pieza, véanse los siguientes trabajos: Grabar, A.: 1963, pp. 48, 129, fig. XVII,I; Pijoan, J.: 1979, p. 137, fig. 207; Firath, N.: 1990, fig. 94; Arbeiter, A.: 1994, p. 10, fig. 2,1.
} 


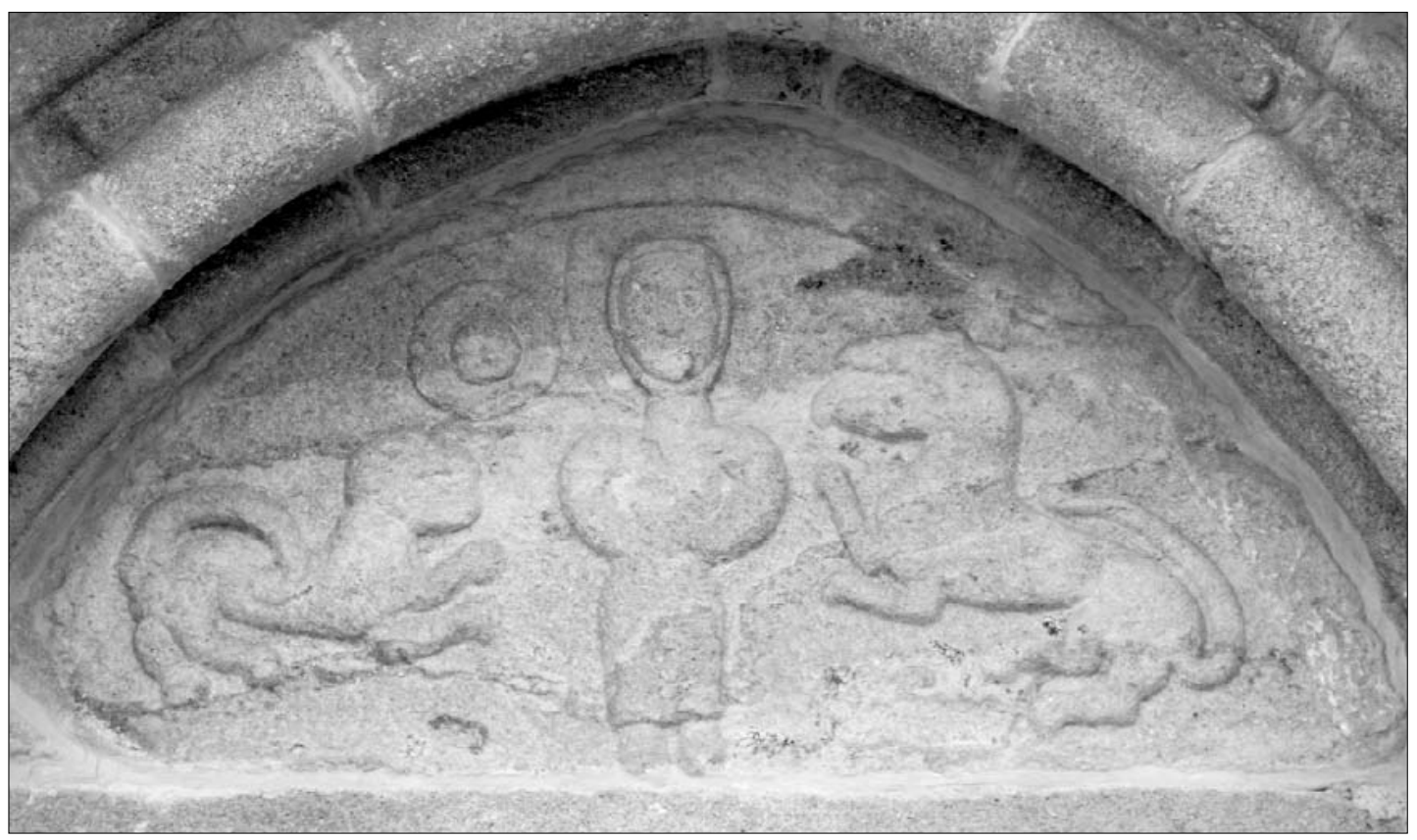

Figura 19. Tímpano de la portada occidental del templo sanjuanista de Santa María de Cela.

El ritual de las palabras Libera, Domine, animam servi tui sicut liberasti Danielem de lacu leonum se apoya, precisamente, en la intervención divina para implorar el auxilio de Dios y su ayuda contra los pericula inferi ${ }^{45}$. Las oraciones fúnebres tales como el Ordo Commendatio Animae que se cantaban en los Oficios de Difuntos y en las que se incluía dicha antífona, son las que mejor reflejan el sentido de súplica de ciertas imágenes, ya que su desarrollo litúrgico coincide exactamente con su afán de ruego y plegaria expresando el deseo de que Dios ejerciese su indulgencia hacia el difunto. La inclusión de dicha plegaria en el ritual de difuntos junto con la interpretación a la que fue sometida la imagen de Daniel desde los primeros tiempos del cristianismo determinó la inclusión del tema en contextos diferentes al de la cabecera, el de las portadas monumentales. En este caso, la iconografía del tímpano fue labrada para una audiencia laica y su ubicación en un lugar como es la portada principal, alrededor de la que se dispone el cementerio parroquial, impone una interpretación exclusivamente funeraria.

A esta intención parece ajustarse la iconografía de una serie de tímpanos en los que se ha reconocido la representación de Daniel $\left(6,13\right.$ y ss) ${ }^{46}$. Uno de los ejemplos más conocido es el de la

45 Reau, L, 1956: 392-393; Màle, E, L'art religieux du XII siècle en France. Etudes sur les Origines de 1'Iconographie du Moyen Age, París, 1922, 12.

46 Para la exégesis paleocristiana, la liberación de Daniel de la fosa de los leones ya era imagen de la resurrección y salvación eterna que aguardaba al cristiano fiel. El hecho de que en la época paleocristiana la mayoría de las escenas aparecieran en un contexto funerario sugirió una explicación ligada a la liturgia y oraciones fúnebres tales como el ordo comendationis animae. Sobre el tema véase: Le Blant, E.: Études sur les sarcophages chrétiens de la ville d'Arles, 1879; Gougaud, L.: "Études sur les ordines commendationis animae", Ephemerides liturgicae, XLIX, 1935, pp. 4-27; del Amo Guinovart, M.D.: "L' Ordo Commendationis Animae i la plástica peninsular dels segles IV-VI d.C", en Spania. Estudis d'Antiguitat Tardana oferts en homenatge al profesor Pere de Palol i Salellas, Publicacions de L'Abadia de Montserrat, 1996, pp. 37-45. En estudios recientes Rocío Sánchez reconoció una intención semejante en algunos tímpanos románicos gallegos ilustrados con el tema de la lucha de Sansón o David con el león. Cfr. Sánchez Ameijeiras, R.: 2001, pp. 168-169. 


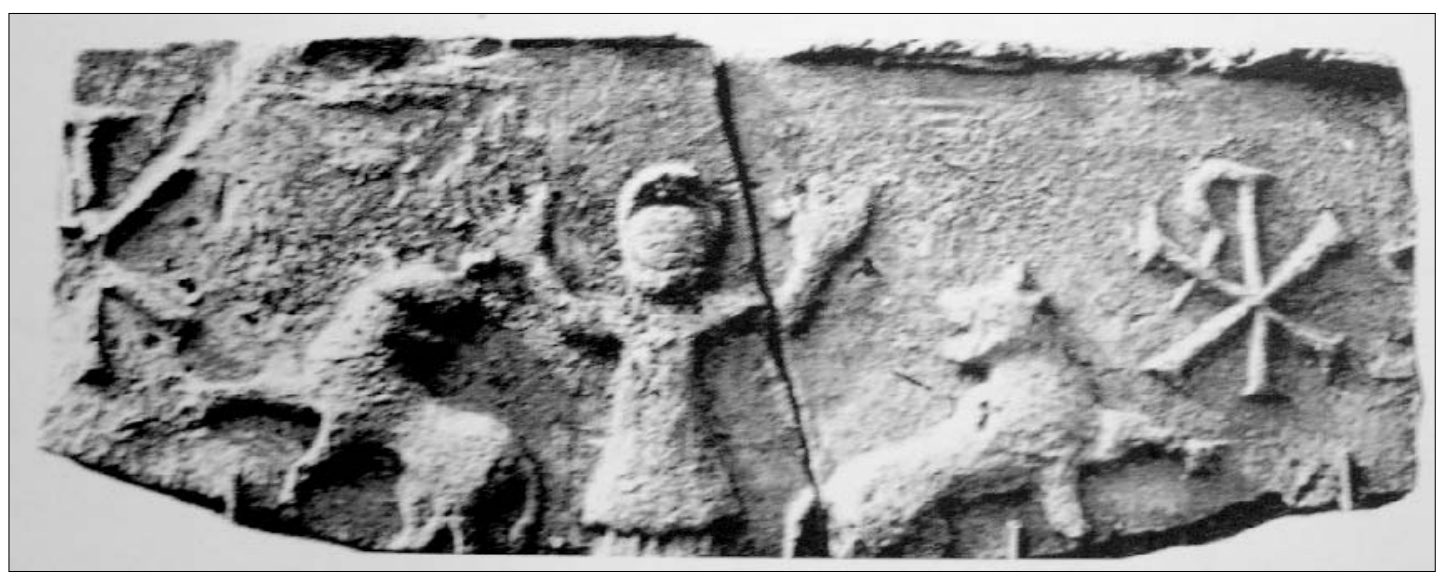

Figura 20. Relieve de un fragmento de ladrillo hallado en Lebrija [Fotografía: Recio, A.: 1978].

portada occidental del templo sanjuanista de Santa María de Cela -Bueu, Pontevedra-47, en cuyo tímpano se representa a Daniel de pie entre los dos leones, ataviado con una larga túnica, con las manos unidas a la altura del pecho en actitud de oración, y sobre su cabeza ostenta el nimbo propio de los justos (fig.19). Sin duda, la singularidad de la imagen radica en el hecho de que a Daniel se le represente con nimbo. En efecto, la imagen de Daniel nimbado presenta una iconografía innovadora en el panorama de la escultura románica gallega. Se trata de una tradición figurativa de la que se tienen noticias, que sepamos, de un único ejemplo en Galicia: en uno de los capiteles del exterior de la cabecera de San Pedro de Rebón: entre imágenes de temática marginal, se representa a Daniel nimbado, en actitud orante, con los brazos levantados y flanqueado por dos parejas de leones ${ }^{48}$. Es precisamente en el ámbito de la miniatura donde se encuentran los precedentes para la representación del profeta nimbado por más que tampoco falten antecedentes en la plástica peninsular, donde podemos rastrear la solución desde épocas muy tempranas; así, en dos fragmentos de ladrillo estampados de época paleocristiana que pudieron haber formado parte del recubrimiento de la pared de alguna cámara funeraria, hallados en el trascurso de unas excavaciones realizadas en el casco urbano de Lebrija, figuran unos interesantes relieves en los que se muestra a Daniel entre los leones y coronado por un nimbo ${ }^{49}$ (fig.20); de la misma época -siglo V d.C- cabe recordar la imagen del profeta Daniel que figura en el ciclo pictórico de la Capilla de la Paz de El Bagawat (Egipto) ${ }^{50}$; también lo encontramos en el relieve de una pequeña placa

47 Bango Torviso, I.G.: 1979; Sá Bravo, H.: 1978, lám. LXXVIII; Durán Gallego, X.E; Verde Lobeira, M; Barreiro y Rosales, B y Barreiro Lobeira, J.: En la ruta del románico. La iglesia Sanjuanista de Santa María de Cela, Pontevedra: Servicio de Publicaciones. Excma. Diputación Provincial de Pontevedra, 1991, p. 63, figs. 13-14; Fontoira Suris, R.: 2001, p. 385.

48 Bango Torviso, I.G.: 1979, lám. XC d); Sá Bravo, H.: 1984, lám. LXVI b). Además del ejemplo de San Pedro de Rebón, también en el templo vigués de Santiago de Bembrive la escena de Daniel entre los leones aparece representada en uno de los capiteles exteriores de la cabecera, asociado a la temática marginal. Sobre el capitel de Santiago de Bembrive: Bango Torviso, I.G.: 1979, lám. C c).

49 Sobre estas piezas, véase: Recio, A.: "Baetica", paleocristiana y visigoda. La antigua "Nebrissa", hoy Lebrija (Sevilla)", Rivista de Archeologia Cristiana, 54, 1978, pp. 23-82, esp. pp. 71-74, figs. 8-9; Arbeiter, A.: 1994, Taf. 1/4.

50 Para las pinturas de la Capilla de la Paz: Fakhry, A.: The Necropoli of El Basawat, Cairo, 1951, p. 74, fig. 65; Stern, H.: "Les peintures du Mouseleé de l'Exode á El Bagaouat", Cahiers Archéologiques, 11, 1960, p. 119; Schlunk, H.: "Un relieve de sarcófago cristiano de Barba Singilia", Archivo Español de Arqueología, 42, 1969, 119-182, pp. 166182, esp. 181-182, fig. 8; Pijoán, J.: 1974, T. VII, pp. 45-50, esp. p. 45, fig. 49; Arbeiter, A.: 1994, Taf. 2/4. 
Figura 21. Arquivolta de la portada occidental del templo benedictino de Santa María de Cambre [Fotografía: Vila da Vila, M.: 1986].

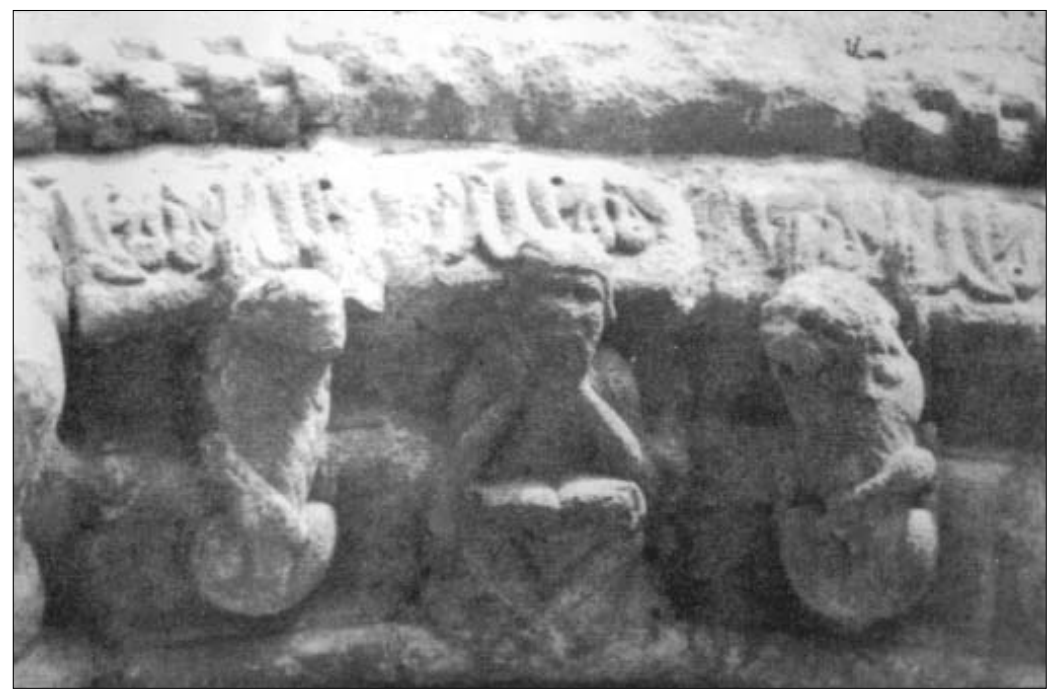

del siglo VI dC procedente de Minieh (Egipto) ${ }^{51}$, así como en varios objetos de uso personal, como acredita alguno de los amuletos de la Moussaieff Collection ${ }^{52}$. Sin embargo, pese a contar con modelos en la plástica paleocristiana, nos encontramos con una tradición que apenas alcanzará relevancia en el ámbito de la escultura románica, si bien en algunos ciclos figurativos de catedrales e iglesias francesas la solución no será del todo desconocida; prueba de ello es la imagen de Daniel que ilustra uno de los capiteles de la nave sur de Ste. Marie Madeleine de Vézelay ${ }^{53}$, en el pórtico meridional de Beaulieu ${ }^{54}$, y también en la portada occidental de la italiana San Fedele de Como.

Por las mismas fechas y con una misma función se talló la imagen de Daniel entre los leones que preside la arquivolta externa de la portada occidental de Santa María de Cambre (A Coruña); aquí se subraya de nuevo la lectura de la salvación eterna a través de la imagen metafórica de la condena de Daniel; en este caso, el episodio está concebido para adaptarse a un contexto diferente: una arquivolta, caso similar al de la portada occidental de Santa María de Ripoll o Santa María de Covet 55. En Cambre, Daniel inaugura una nueva solución figurativa; en este caso se aleja de la caracterización tradicional y se le representa como un hombre de edad avanzada, barbado, sentado entre los dos leones, con las piernas cruzadas y el rostro apoyado entre las manos, que sostiene un libro abierto sobre sus rodillas 56 (fig.21). La iconografía de Daniel como un hombre de avanzada edad no es ignorada en los programas escultóricos medievales o en la propia tradición figurativa de los manuscritos iluminados, si bien no suele predominar. En el ámbito de la escultura

\footnotetext{
51 Arbeiter, A.: 1994, pp. 9-10, Taf.2/3.

52 Dicha pieza figura en la siguiente dirección: http://www.usc.edu/dept/LAS/wsrp/educational-site/other-collections/moussaieff/mo.

53 Pijoán, J.: El arte románico. Siglos XI y XII, en Summa Artis. Historia General del Arte. T. IX, Madrid: Espasa Calpe, S. A, 1973, p. 179, fig. 263; Huys Clavel, V.: La Madeleine de Vézeley. Cohérence du decor sculpté de la nef, Éditions Comp’Act, Conseil Genéral de 1’Yanne, 1996, pp. 121, 123, nº 27; William, J.: 2000, p. 55, fig. 5.

54 Porter, K.A.: 1923, fig. 419; William, J.: 2000, p. 58, fig. 11.

55 Porter, A.K.: 1923, fig. 578; Melero Moneo, M.: 2003, pp. 141-142, fig. 6. También se repite en la arquivolta externa de Santa María de Covet; Yarza Luaces, J.: "Aproximació estilística i iconográfica a la portada de Santa María de Covet", Quaderns d’Estudis Medievais, 1982, pp. 535-556. p. 464.

56 Vila da Vila, M.: La iglesia románica de Cambre, La Coruña, 1986, pp. 65-66, fig. 22; Yzquierdo Perrín, R.: 1993 ,
} 
románica gallega, aunque muy distintos entre sí, el Daniel que figura entre la serie estatuaria de la portada occidental de San Xulián de Moraime está caracterizado como un anciano, de larga barba, ataviado con indumentaria litúrgica y portando en sus manos una larga cartela desenrollada ${ }^{57}$.

Nos interesa aquí, sobre todo, subrayar la poco convencional actitud del profeta: sedente, con la cabeza apoyada en las palmas de las manos y concentrado en el libro que tiene ante él. Para Green, la imagen de Daniel sentado y meditativo, con la cabeza apoyada en una mano - grupo iconográfico muy extendido por las zonas de Borgoña y Nivernais-, expresa, por su actitud, su capacidad visionaria: es el Daniel de los sueños y de las visiones ${ }^{58}$. Esta interpretación resulta del todo acertada al valorar la complementariedad del propio libro; según Vila da Vila, con la presencia del libro se capta una de las visiones del profeta, quien profetiza que en el Juicio Final cuando sean abiertos los libros (Dan. 7, 10), en los que figuran escritas las buenas y malas obras de los muertos, sólo se salvarán de la segunda muerte aquellos que estén inscritos en el Libro ${ }^{59}$. Se impone así la práctica del examen de conciencia, y la imagen de Daniel se convierte en una metafórica referencia a la recompensa de la resurrección que aspira a alcanzar el buen cristiano en el último juicio al que se alude en uno de los capiteles en el que figura el arcángel san Miguel pesando las almas. En este caso está claro el valor explicativo del libro; sin embargo, existen otras representaciones en la escultura románica gallega en la que se subraya la complementariedad de este atributo y en las que no podemos precisar hasta qué punto posee este mismo valor o si su significado pudiese relacionarse con otras equivalencias: recordemos la escena de la condena de Daniel que figura en la portada de la iglesia de Santiago de A Coruña, en el Daniel de la catedral ourensana, en San Salvador de Ferreira de Pantón ${ }^{60}$, en San Estebo de Carboentes ${ }^{61}$, o, ya en épocas posteriores, la que ilustra uno de los capiteles de la Claustra Nova ourensana ${ }^{62}$.

Es precisamente en la catedral ourensana, concretamente en el ciclo figurativo que decora el muro occidental de la nave norte, donde se encuentra la más explícita figuración simbólica de la salvación. Aquí el discurso ascensional de imágenes intentando superar los ataques de una serie de figuras representativas del pecado se inaugura en el tímpano de la portada de acceso a la torre con la imagen de Daniel sedente, entre dos leones y concentrado en la lectura de un libro. Recientemente, Sánchez Ameijeiras ha propuesto para este ciclo una lectura iconográfica asociada al proceso del ascenso espiritual del alma ${ }^{63}$. Con la inserción de Daniel se crea un choque emotivo

57 Sousa, J.: "La portada occidental de la iglesia de San Julián de Moraime", Cuadernos de Estudios Gallegos, XXXIV, 1983, pp. 155-178, esp. pp. 167-168, figs. 5-6. En cuanto al motivo de la cartela desplegada, se trata de un atributo habitual de los profetas de la iconografía cristiana aunque poco habitual en nuestros programas figurativos en los que, además de la imagen del profeta Daniel de la serie estatuaria del Pórtico compostelano, lo encontramos en una modesta representación que se exhibe en uno de los capiteles del arco triunfal del templo parroquial de Santa María de Frades (A Estrada, Pontevedra). Sobre este capitel, véase: Bango Torviso, I.G.: 1979, lám. LIX f); Yzquierdo Perrín, R.: 1993, T. X, p. 283.

58 Green, R.B.: Daniel in the Lions 'Den as an example of Romanesque tipology, Ph. D. diss, University of Chicago, 1948, pp. 7, 46-48, 74. Cit. por Williams, J.: 2000, p. 69, not. 19. En el arte monumental hispánico de época románica únicamente conozco el precedente que figura en uno de los capiteles del crucero de la Colegiata de Santa María de Toro (Zamora). Sáinz Sáiz, J.: El Románico en Zamora, León: Ediciones Lancia, S.A, 1999, p. 65.

59 Vila da Vila, M.: 1986, p. 68. También en el Apocalipsis de San Juan existe una alusión al juicio de los muertos y a la apertura del Libro: "Y vi a los muertos, grandes y pequeños, de pie delante del trono; fueron abiertos unos libros, y luego se abrió otro libro, que es el de la vida; y los muertos fueron juzgados según lo escrito, conforme a sus obras" (Juan XX, 12).

60 Enríquez Flórez, Ma . F.: 1976, pp. 125-159; Idem, 1999, pp. 189-121; Yzquierdo Perrín, R.: 1991, pp. 854-875; Yáñez Neira, D y Tobío Cendón, R.: 2000, p. 28; Moure Pena, T.C.: 2001, pp. 68-69, figs. 47-48.

61 Sá Bravo, H.: 1978, p. 798; Bango Torviso, I.G.: 1979, lám. XVIII j); Izquierdo Perrín, R.: 1993, p. 323; Fontoira Suris, R.: 2001, p. 482.

62 V.V.A.A.: A catedral de Ourense, col. Patrimonio Histórico Galego, T.I, Catedrais, La Coruña: Xuntanza Editorial, 1993, p. 101, fig. 120; Ferrín González, J.R, Carrillo Liste, P.: 1999, p. 264, lám. 4.

63 Sánchez Ameijeiras, R.: 2001, 162-163. 
susceptible de conmover la conciencia, es decir, de establecer una comparación rápida entre la debilidad de la condición humana y los pecados a evitar, y la imagen del profeta cual exemplum del principio de la perfección cristiana y testimonio de la fe profunda, virtudes a alcanzar para todo cristiano que aspire a la salvación eterna.

Recibido: $17-\mathrm{XI}-2004$

Aceptado: 26-V-2005 